\title{
Epistemic Regards on Food as a Commons: Plurality of Schools, Genealogy of Meanings, Confusing Vocabularies
}

\author{
José Luis Vivero-Pol ${ }^{1,2}$ \\ Universite Catholique of Louvain, 1348 Louvain-la-Neuve, Belgium \\ Email: jose-luis.viveropol@uclouvain.be

\footnotetext{
${ }^{1}$ Biodiversity Governance Research Unit (BIOGOV), Center for the Philosophy of Law (CPDR) - UCL
} \\ ${ }^{2}$ Earth and Life Institute, Faculty of Biological, Agricultural and Environmental Engineering - UCL
}

\begin{abstract}
Commons and food are experiencing a revival in recent years and yet the links between both are almost absent in academic and political discourses. Commons are often portrayed as historical and yet innovative governing mechanisms that can challenge the State-Market hegemony. On the other side, food is both a relevant agent of change and a major driver of planetary destruction, being thus cause and solution to multiple crises that affect humankind. Departing from the commodification of food as one root cause of the broken global food system, this text firstly situates and discusses the different schools of thought (or epistemologies) that have addressed the private/public, commodity/commons nature of goods in general, and then explores how those schools have considered food in particular. To do so, the author has defined five epistemologies, four academic (economic, legal, historical and political) and one non-academic (grassroots activists). The analysis highlights how those epistemologies have yielded incommensurable understandings and conflicting vocabularies, hence creating confusion in the socio-political realm and even rejection around the idea of food being considered as a commons. The economic epistemic regard has reigned over the others by applying an approach to commons, public and private goods that is theoretical, reductionist and ontological instead of phenomenological, therefore preventing or obscuring other scholarly or practical understanding of commons. When applied to food, the iron law of economics dictated that food, a private good based on rivalry and excludability, shall be better allocated through market mechanisms with absolute proprietary rights and valued as a pure commodity. This reductionist view collides with the plurality of meanings of food in different societies, civilisations and historical periods, as other schools of thought indicate. The author uses diverse epistemic tools to re-construct food as a commons, based on its essentiality to human beings and societies and the customary and contemporary praxis to produce, consume and govern food collectively through non-market mechanisms for more than 2000 centuries. As commoning has instituting power to create different political and legal frameworks, if food is valued differently the entire architecture of the global food system would change, as the grassroots activist school claims. Re-commoning food defies the legal and political scaffoldings that sustain the hegemony of market and state decision-makers over eaters and food producers and informs sustainable forms of food production (agro-ecology), new collective practices of governance (food democracies) and alternative policies to regain control over the food system (food sovereignty). Food as a commons is an agent of change with transformative power, no matter what economists say.
\end{abstract}

Keywords: food; commons; epistemologies of food; commons epistemologies; food narratives; food values; public good theory; academic schools; paradigms 


\section{1.- INTRODUCTION}

The commons are back...if they were ever gone. The multiple global crises the world has been facing in the last decades have prompted scholars, policy makers and activists to seek for solutions that enable us to live satisfying, fair and sustainable livelihoods within planetary boundaries. And the commons appear as one of the most promising transition pathways to replace the neoliberal model due to a proven historical record of resilience, collective governance and sustainability and, secondly, an inspirational narrative based on solid moral grounds. Commons thinking expresses a strong denial of the idea that society is and should be composed of atomized individuals, living as rationale consumers seeking individual profit maximisation, always competing with other individuals to thrive ${ }^{1}$. Actually, the narrative of the commons was cornered by possessive individualism (Macpherson, 1962), rational choice (Schelling, 1984), social Darwinism (Leonard, 2009) and the famous "tragedy of the commons" (Hardin, 1968 in Box 1). Instead, the commons discourse recognises that people shall live their lives as aware individuals deeply embedded in, and not against, social relationships and the environment. Moreover, individuals' active participation is essential to realizing collective and personal goals, moving away from a purely individual rights-, market-based and private-property worldview.

The commons entered in the political and social agenda since the 80 s, growing in parallel with the commodification process that was accelerated in the last quarter on XX century (Appadurai, 2005). Although for decades the commons have been dismissed as a failed system of governance and resource management (Bloemen and Hammerstein, 2015), they have gradually being rehabilitated in the legal, political and economic domains, especially in the environmental and knowledge realms (Benkler, 2013; Capra and Mattei, 2015). There is a growing recognition that the so far hegemonic duet market-state with their capitalist system and individualist ethos is inadequate to tackle the global and multiple crises we, as a society, confront these days. Moreover, new socio-economic paradigms are emerging as alternative narratives and praxis $t$ the hegemonic neoliberal version of capitalism (i.e. happiness, de-growth, Buen Vivir, resilience, transition, sharing economy, peer-production). Innovative commons-based initiatives are mushrooming all over the world, often in response to the economic crisis and austerity politics, with examples ranging from the local level (i.e. the maintenance of communal forests owned by medieval parishes in Galicia villages), the national level (i.e. the path breaking initiative promoted by the government of Ecuador to design collectively public policies that can support knowledge commons ${ }^{2}$ ), to the regional one (i.e. the first European Citizens' Initiative that demanded water to be treated as a public good and commons ${ }^{3}$, members of the European Parliament establishing a Commons Intergroup $)^{4}$.

The commons are all over, they have always been, since the onset of the human societies, and they will be there (hopefully) for many centuries. They are, at the same time, a very ancient and rather innovative framework to govern natural resources and non-material items that are essential to human survival. Actually, one can say without being wrong that the history of human civilizations is a history of commons and public goods (Wolf, 2012). It is precisely the antiquity and essentialness that explain the multiple meanings and often diverging interpretations of this rather polisemic word. The commons fulfil religious, cultural and environmental functions, and are of particular importance for securing the livelihoods of poorer members of society, including women and the landless (Federici, 2014; Fuys et al., 2008). Additionally, there are many subsistence commons that rely upon self-governed access and

\footnotetext{
${ }^{1}$ This idea is epitomized by the Latin sentence "Homo homini lupus" created by Plauto (254-184 B.C.) and rendered popular by Thomas Hobbes (1588-1679). The opposite narrative is however defended by authors such as de Waal (2006: 3), Bowles and Gintis (2013) or Kropotkin (1902).

${ }^{2}$ http://floksociety.org/

${ }^{3}$ http://www.right2water.eu/

${ }^{4}$ http://commonseurope.eu/
} 
use of forests, fisheries, pasturelands, farmlands, coastal lands, bodies of water, wild game, and other natural resources. An estimated two billion people around the world depend on commons for their daily food and everyday needs (Weston and Bollier, 2013; Fuys et al., 2008). These areas, although often classified as public lands or private property owned by communities, are collectively-owned and self-governed by their inhabitants, very often through common property arrangements (Meinzen-Dick et al., 2006).

\section{Box 1.- The tragedy of the Commons: Hardin vs Ostrom}

According to classic economic theory, the most usual problem created by common-property resources is the tendency for them to be overexploited to the point of exhaustion or extinction, if there is free and open access to them in which people not paying for the good may continue to access it (Hardin, 1968). Throughout the world, natural fisheries, common grazing pastures, forest resources and biodiversity are also examples of open-access resources prone to the tragedy of the commons (i.e. biopiracy, over-exploitation). In North America, recent problems with salmon and lobster fishing illustrate situations in which common-property resources in food production are involved, with Canadian native peoples being prohibited their access to fishing salmons in rivers and fishermen in US being forced to fulfil federal laws that do not consider their customary governing mechanisms (Rocha, 2007). And yet, thousands of successful and enduring examples of local communities managing common resources can be found in the scientific literature and real life, from Maine lobster fisheries to Alpine pastures or Asian rice paddle-fields.

Some common goods may be subject to excessive use resulting in negative externalities affecting all users. Fish in the oceans and mushrooms in the forests are renewable resources in that their stocks can be replenished as long as the rate at which they are harvested is lower than the rate at which they can reproduce themselves. The problem with free, open-access common resources is that they tend to be harvested at a faster rate than they can naturally replenish themselves. Without governing mechanisms, each resource taker would have an incentive to take as much and as fast of this common resource as he could. That is why most commons, when so consider, have already in place governing mechanisms.

Up to recent times, the debate on the best governance of common goods was circumscribed to the state or the market. The Hobbesian solution portrayed in the Leviathan (Hobbes, 1651) acknowledges human selfishness and the subsequent trend to free-riding and thus the only possible solution to govern the commons and avoid its tragedy is through a centralised state and its regulatory force of public ownership. On the contrary, the Lockean solution assumes that common property prevents the optimal use of a good as no incentives are provided to keep and care for it and only fully privatised ownership can work. However, private property is not the only (or the most practical, or fair, or effective) way of dealing with this externality problem. Actually Elinor Ostrom and her colleagues showed, drawing from both field studies and theoretical and laboratory work, that alternative forms of property and governance can work if they match "attributes of the resource and users, and when the resulting rules are enforced, considered legitimate, and generate long-term patterns of reciprocity" (van Laerhoven and Ostrom 2007: 19). The merit of Elinor Ostrom's theoretical and practical research was to offer a convincing experience-based third model: one of emergent localised polycentric governance of complex economic systems (Ostrom, 2009), where self-motivated collective actions by local groups had also an important role to play in governing natural resources ${ }^{5}$.

\footnotetext{
${ }^{5}$ And yet, Ostrom's approach was also criticized as being quite micro level, in closed commons where entitled members were clearly defined by social and physical boundaries and non-members could not benefit from the commons.
} 
The tragedy of the commons in economic terms is rebranded as social dilemmas in the political sphere (Kaul et al., 2003), since all those who benefit from the provision of a local public good find it costly to contribute and would prefer others to pay for the good instead. If everyone follows the selfish dominant strategy, then the good is not provided or underprovided. Yet, everyone would be better off if everyone contributed. In those situations of social dilemmas, institutions introduce a certain level of collective constraint, whether through formal or informal rules (such as social norms and intrinsic preferences), with the aim to produce better outcomes (Ostrom, 2005). Another political dilemma rather relevant these days is that "public" no longer means the communities that manage their local resources, but the central governing authority that controls these resources, namely the State. In theory, public still means people; in practice, public often means government decoupled from the people's social/ecological rights to their common goods (Quilligan, 2012).

As a corollary to Hardin's conclusion, neoliberal economists argued the only efficient rules that limit access to the common pool resources are alienable private property rights (Aguilera-Klink, 1994) that are protected through legal frameworks that give precedence to this right over other rights essential to preserve life, such as the right to water, food, health and housing. Thus Hardin's conclusions joined with neoliberalism to not only reject common property but also state property as reasonable ways to organize the use of essential commons for humans such as land, water, food, fish, seeds or forests.

However, the ubiquity and importance of commons for human societies is not equalled by the consideration assigned by the ruling elites and ruled citizens in urban areas. Although widespread, the commons are not usually seen because we are not taught to appreciate them in this apparently dichotomist world (either privately-owned or state-owned goods), in what seems to be an ironical paradox: the commons are victims of invisibility and lack of appreciation by general public, policy makers and the media while they continue sustaining our entire livelihood, our societal organisations and our current economic model that predates on them. The disregarding and oblivious stance of the ruling elite and the media controlled by them helps explain the absence of commons from peoples' consciousness. Among the several examples of life-enabling commons that are not given due political priority, there are pollinators' or soil fungi's role in maintaining agriculture as we know it, the unpaid work usually done by women to take care of elders and ill people affected by chronic diseases, the regulatory work the sovereign states undertake to maintain currency stability at global level, balancing the speculative movements often undertaken by corporate financial actors or the stewardship of beaches, sea cliffs and estuaries by communal, local and national entities that enable us to enjoy free access to coastlines. From sea food to public squares, from Mozilla software to public libraries or cooking recipes, commons are so close to our daily lives and yet so undervalued in our commoditised economy.

More importantly, the notion of the commons has being extensively and increasingly used as a paradigm of convergence of different struggles against neoliberal capitalism and the multiple enclosures it entails. Actually, the term can be seen as a catch-all concept (Perilleux and Nyssens, 2016) with academic contributions evolving in parallel with practical developments by activists. However, this widespread use of the commons terminology, often in a very uncritical way, has infused them with a mystic aura of social avant-garde and repository of all the virtues of horizontal and fair governance (Verhaegen, 2015). In doing so, it risks to become an empty slogan. As Rodota already warned in 2013, if "everything is a commons, nothing is a commons" (2013: 8). Therefore, the commons vocabulary shall be defined better and their conceptual boundaries have to be determined, so as to defend its uniqueness and prevent the void of its transformational power. 


\section{1.a.- The aim and components of this chapter}

In this chapter, I seeks to shed light on the different epistemic views that have addressed the private/public commodity/commons nature of resources and goods in general, and then he analyses how those schools have explored the normative valuation of food, assigning food to the different categories of private good, public good, commons, common pool resources or commodity ${ }^{6}$. I depart from the absolute commodification of food as one of the underlying causes of the current crisis of the global food system that consumes $70 \%$ of total water resources, depletes arable soils, deforests forests, contributes with more than one third of global warming gases, pushes biodiversity to the verge of extinction, erodes human-made germplasm diversity, evicts small farmers and peasants from their farms, wastes one third of total food produced and uses more than $50 \%$ of available food to nonhuman consumption purposes. This broken food system needs to be drastically modified from the very pillars. In that sense, the question of what type of food system we aspire to craft cannot be divorced from the question of how we value food, what type of food we want to eat, with whom we share, cook and eat food, how we expect to steward the food systems that yield our food and what type of livelihood we wish for the producers of the food we eat. If we aspire to a food system that is based on the notion and principles of commons, we need not only to explore the idea of food as a commons, but also to define what we mean by commons.

In order to do so, I firstly situate and discuss the different schools of thought (or epistemologies) on the commons, classifying the approaches into five schools (economic, legal, historical, political and grassroots activists), and then I provide conceptual clarifications on the applicability of the "commons" concept to food under different epistemic regards. Epistemology is how we know about the world, meaning the different stances to collect, analyse and interpret data, inputs and stimuli from natural and human-made events. Epistemologies determine what constitutes acceptable sources of evidence, acceptable methodologies to analyse and interpret reality and acceptable findings (Tennis, 2008) and they can b, among others, pragmatic, theoretical, positivistic or empiricist. Obviously, what one thinks food is depends upon how one perceives and judges it and those different conceptions are connected to different beliefs and ways to know (Kaplan, 2012). Different realms of academic disciplines have addressed the commons and food by using different cognitive tools, accumulated knowledge and personal values, all of them forming particular epistemologies.

Throughout the chapter, it can be noted how the different meanings of the commons to different people and scholars often results in incommensurable epistemologies and vocabularies, creating confusion and even rejection around the idea of food being considered as a commons. These contradictions between vocabularies, meanings and epistemologies will be analysed in the discussion and conclusion parts. As a matter of fact, none of the major authors approaching the commons has described food in these terms (Karl Polanyi, Karl Marx or Elinor Ostrom) and even food and nutrition security, a situation that is certainly beneficial for all and detrimental to none, is not considered today as a Global Commons or Global Public Good, with just a few exceptions such as the work of Hans Page (2013).

This chapter will be articulated around the following sections, firstly different typologies of commons will be presented and discussed so as to portray an idea of the richness and complexity of the concept of commons, already yielding multiple definitions and real-life examples; then an extended section will be devoted to the five epistemologies of commons that have been crafted by the author, namely the economic, legal, historical, political and activist schools of thought, being the latter one the only nonacademic. Once the value-based approaches to commons in general have been analysed, there is a

\footnotetext{
${ }^{6}$ Although the main objective of this text is to understand the different epistemic regards that value food as a commodity or a commons, other closely related normative discourses considering food as private or public good will also be analysed.
} 
section on epistemologies of food where I explore the applicability of the different understandings to food resources in particular. In this section, the economic, legal, historical, political and activist rationalities are applied to food, the normative nuances are exposed and the dominant narratives on food as a commodity are debunked. Finally, in the discussion and conclusions I defend the idea that all but the economic epistemology accept the idea that food can be valued and governed as a commons, but the hegemonic dominance of the economic narrative and vocabulary in the second half of XX century has overshadowed the other understandings of food as commons. And yet, due to the multiple crises the current globalised food system is experiencing (climate change as a threat to food production, rising obesity pandemic, hunger still prevailing in a world of plenty, food wasted to maintain artificial scarcity, open food markets just seeking profit maximisation and not guaranteeing people access to enough food, industrial food system being the major driver of exhaustion of Earth's natural resources), other narratives of food are either emerging within contemporary alternative food movements or being revamped within customary food systems. Those narratives are legitimised by the academic epistemologies as well as the grassroots activists.

\section{2.- DIFFERENT TYPOLOGIES TO DESCRIBE THE COMMONS}

As discussed above, before I explore the epistemic views on commons and food, it is important to understand the different typologies that have been constructed to classify the commons. The diversity that is so inherent to the commons (multiple collective arrangements, proprietary regimes, varied natural and immaterial resources, cultural considerations, cosmovisions) is mirrored by the diversity of approaches, typologies and epistemic regards that have analysed the polysemic meanings of the commons. The first typology hinges on the normative purpose while the second one is grounded on the resource characteristics. The first one distinguishes between moral and operational notions, being the normative approach the one that explores what commons should do and what are meant for, and the operational approach the one that describes what commons actually do, by analysing the resources and the governing mechanisms. The second typology, however, departs from the resource characteristics to define the ontological approach; being the phenomenological approach the one that embraces the situated commoning and the purpose. Although different, they are all characterized by incorporating in the definitions three analytical components of the commons: resource, the governing mechanism (commoning) and the normative purpose.

\section{2.a.- Operational and normative definitions: useful, real and transformative}

On the one hand, the commons can be interpreted as shared resources (material or immaterial) that are governed by a certain community with self-regulated rules. On the other hand, seen through a moral lens, the commons can be interpreted as goods that benefit society as a whole and are fundamental to people's lives, regardless of how they are owned, produced or governed.

The operational rationales, fitting better with the scientific epistemologies, are then enriched by (a) utilitarian narratives and (b) descriptive narratives. The former place the emphasis on describing the practical aspects of ownership, management, definition of boundaries, proprietary regimes, nature of the resource and the community that manages/owns the commons. It seeks to prove that commons are useful for human livelihood and the sustainability of the resource, either material or non-material. The latter are based on historical accounts and current research on the commons, rendering explicit how the commons were created by communities and governed by different peoples and cultures in the past and by non-dominant cultures at present. This rationale aims to render visible the customary and contemporary commons and to understand how they managed to endure for such a long period (i.e. alpine meadows) or how they are created de-novo in our society (i.e. Wikipedia).

The normative narratives are more aspirational, utopian and justice-based, detailing how the commons could become a moral alternative to the dominant hegemonic discourses of capitalism, 
individualism and competition. In this sense, the commons are presented as alternatives to the multiple crises that are intertwined with the economic model, planetary boundaries, energy, environment and essential resources for humans, such as food, water, land, seeds etc.

\section{2.b.- Ontological and phenomenological approaches: theoretical constructions, instituting power}

This typology is rooted in Ancient Greek philosophy and defines the commons using two sets of attributes: the intrinsic features of the goods and resources (either material or immaterial such as knowledge or international agreements) or the perceptions, values or social practices that humans have around any given resource or action. This typology has been used by Van Tichelen (2015), Perilleux and Nyssens (2016) and Ruivenkamp and Hilton (2017) with different variations.

The ontological approach, also called essentialist by Van Tichelen (2015), determines that a good is characterised by its intrinsic attributes. In other words, the inner properties of the good (its nature) determine its relational bonds with humans and hence the property regimes and the most adequate institutional design to achieve a purpose. This approach is atomist (commons can be subdivided into resources with natural characteristics, boundaries, rates of growth, proprietary regimes and institutions that govern them) and helps understand how specific parts of the commons function. However, it tends to ignore the relational components, the phenomenological approaches and the impact of social norms and place- and time-constraints. In that sense, this approach is often used in academic and normative circles, largely in economy-dominated milieus. Actually, it has been adopted, with a nuanced reductionist consideration, by the neoclassical economists that developed the theory of public and private goods (see later in this chapter). And yet, ontological categories and closed legal definitions are exactly the kind of mindset the commoners living and working in commons seek to challenge.

On the other hand, the phenomenological approach understands the commons as a social construction (commons are determined by people in particular circumstances) and hence they are always situated (Szymanski, 2016) and relational (Verhaegen, 2015). This approach pivots around people acting together as the agents that assign value to resources and design the most appropriate ways of governing those resources to achieve concrete goals. Based on moral grounds some goods have to be considered, owned and governed as a commons because they are essential to humans. The proprietary rights and the governance mechanisms can be diverse as long as the main goal is achieved: guaranteed access to those essential goods to all as a matter of social justice and legal entitlements. Although commons are often associated to property regimes and governing mechanisms (Perilleux and Nyssens, 2016) they cannot be solely and always described based on who owns and who governs them. Actually, commons can be owned privately and governed by public institutions (Gerber et al., 2008) (ie.g. hunting permits in private lands in Switzerland), be owned collectively and governed by the state (Serra et al., 2016) (e.g.. communal forests in Portuguese baldios), or be owned publicly and governed by private entities under regulated conditions (Allouch, 2015) (e.g.. beach concessions to hotels in many countries).

Between those two typologies, Perilleux and Nyssens (2016) consider Elinor Ostrom, an economist that researched the political, institutional and behavioural features of commons, common-pool resources and commoners, as a sort of bridge between theorists and practitioners, since she and her colleagues navigated between the different but complementary epistemic regards, the ontological economic view and the phenomenological constituting power, with hundreds of real case-studies investigated in detail in multiple countries and scenarios.

Finally, an interesting phenomenological classification has recently been developed by Etienne Verhaegen (2015), according to whom commons can be analysed as institutions, universal rights, social practices and politics. 
Utilitarian commons (Useful institutions). Understanding commons as useful institutions puts emphasis on their utilitarian purpose. This approach sees the self-regulated governing mechanisms as a useful and efficient way to govern natural resources and it studies in detail the nature of the local resources, their boundaries and the characteristics of the governing communities. Commons are defined as shared resources governed collectively and they can be owned in different forms (private, public and collective). This approach rejects the resource-based definitions (such as the economists') as well as the property-based definitions (such as the legal scholars').

Moral commons (commons as universal rights). For the supporters of this understanding, considering any given resource (material or non-material) a commons is grounded on its essentiality to human survival and its irreplaceability for other resource, what qualifies the resource as a universal right to be governed as commons (Rodota, 2013: 8). These commons shall be accessible and benefit all (for the common good), including the present generation and the coming ones, simply by a matter of justice. By applying a moral rationality to the concept, this understanding surpasses the utilitarian approach described above and connects it to the understanding of commons as public goods beneficial to the community.

Social commons (commons as social practices). This understanding defends that it is the social practice of commoning ${ }^{7}$ that makes the commons and through the commons the individuals re-affirm their autonomism, i.e. the social bonds with other members and construct a common set of values that give a meaning to their lives (Verhagen, 2015). Commoning creates new rules, moral principles and valid narratives, and has even instituting (Dardot and Laval, 2014) or constitutional power (Capra and Mattei, 2015). A commons arises whenever a given community decides it wishes to manage a resource in a collective manner, with special regard for equitable access, use and sustainability. This approach downplays the importance given by the previous approaches to entitlements to, membership or boundaries of commons and, conversely, rises the profile of commons as a space of autonomy and self-governance. This approach to the commons may choose three different pathways to develop: being totally apolitical in their goals, the political disaffection with broader constituencies not willing to get engaged in social claims (often term as alter-hegemonic constituency) and the political activism and self-awareness of working at community level but with a greater global objective (often dubbed as counter-hegemonic) ${ }^{8}$. The first type would remain here whereas the latter two would be better placed in the next type.

Political commons (commons as transformational politics). Many scholars and activists from different disciplines understand the commons as a transformational narrative that aims to de-commodify multiple spheres and resources. The commons are perceived as an alternative narrative that opposes to the free market logic and the central sovereign state, as both entities are locked in a mutually supportive dialectical relationship, as nicely depicted by Polanyi (1944) in the theory of the doublemovement or recently by Capra and Mattei (2015) in the Ecology of Law. Commons become counterhegemonic (McCarthy, 2005; Johnston, 2008) and use legal reforms and political claims to gain legitimacy, visibility and leverage power. People participating in commons can be profiled as Homo cooperans (De Moor, 2013) an archetypical representation radically different from the dominant narrative of Homo economicus.

After this quick review of different typologies to understand and classify the many commons human societies have designed, I will explore in further detail five type of understandings on the commons in general and on food in particular, including four academic school of thoughts and one grassroots

\footnotetext{
${ }^{7}$ Commoning is defined as doing things together for the common good of myself, the others and the coming generations, based on a moral ground different from the prevailing one of capitalism.

${ }^{8}$ See Vivero-Pol, 2017 for a detailed analysis of both political streams.
} 
epistemology. This exercise seeks to understand how normative valuations of food, based on different epistemic regards, have yielded a diversity of meanings, vocabularies and opposing conceptions both synchronically and diachronically.

\section{3.- EPISTEMIC REGARDS ON COMMONS: PLURALITY OF MEANINGS AND DEFINITIONS}

There is little doubt that the academic and grassroots "commons landscape" is complex and varied. It embraces different epistemic regards, academic approaches and operational constituencies. The commons have different readings (Mattei, 2013a) each one with its different trajectories and implications. Legal, political, economic, cultural and ecological approaches talk about commons and inform knowledges and ideologies that are then reflected in the creation of different schools of thought and vocabularies that examine, interpret and influence our understanding of the nature of the commons. As resources important for human beings, commons have "multiple personalities" (Wall, 2014) and therefore multiple phenomenologies (Mattei, 2012) and vocabularies are accepted to describe them (see Box 2). This builds upon the notion of legal pluralism (Engle-Merry, 1988) and institutional diversity (Ostrom, 1990). The plurality of definitions of the commons in the public and academic discourses renders difficult to reach a consensus on which resources, situations and policy decisions are deemed to be considered as commons or for the common good. This situation affects food directly, with its commons category being strongly contested in academic and political domains (Vivero-Pol, forthcoming a; Vivero-Pol and Schuftan, 2016). One source of discrepancy on understanding the commons stems from the fact that collective ethical notions on what is a commons, as defined by a community (social construct), are mingled with individual theoretical approaches by influential thinkers (those coming from the economic school) and binding political decisions made by elites (political approach to commons).

\section{Box 2.- What do commons mean today for people?}

Tracing the genealogy and evolution of the meaning of commons may help us explaining the prevailing significance for the elites and the common people (Foucault, 1993) and it may inform the entry points to unveil other meanings that were either prevalent in ancient times or that could be unfold in coming futures. In this way, we could inquire on the origins of the current understanding of the commons, which appears as the result of the evolution of the concept across history since the understanding and valuation of the commons in late Middle Ages in Europe. But, the genealogical considerations also help questioning how the economic definition of the commons, that was crafted by Western scholars and utilized in a specific context with clear objectives, became dominant and why it is still prevailing nowadays.

Over time, the word "commons" has assumed several different meanings, no longer just restricted to natural commons, material goods or local scale, but also referring to non-material goods (i.e. knowledge, software), political institutions and services (global food safety, peace) and global issues (climate change and ozone layer). Some known expressions of the term "commons" are commonwealth, communalism, common land, the UK House of Commons, "for the common good" and others that imply cooperation and collaboration of people in society, living together and working in their common interests. More specifically, in the popular meaning "commons" are resources owned and managed in common because they are beneficial for all members of the community. However, the idea of commons is also subject to misunderstandings and confusions. For example, the economic concept of the commons (or public goods) should not be mistaken with the expression "for the common good" (or "for the public good"), which is usually an application of a collective ethical notion of "the good" in political decision-making. Another typical confusion is to think that commons are goods provided or to be provided by the public sector or the Government. Although it is often the case, they may also be produced by private individuals and firms, by non-state collective action or they may 
not be produced at all (naturally-made as sunlight). Additionally, the commons contains public, collective and private properties, over which people have certain traditional rights.

Different realms of academic disciplines have addressed the commons by using the epistemologies (cognitive tools and accumulated knowledge) that characterise each discipline, be that economics, law, history, politics or grassroots activism. These epistemologies have been mingled with dominant ideologies and politics, as the academia is often influenced by the ruling elites (Wallerstein, 2016). These different approaches to a complex, varied, place-based and multi-faceted theme have shaped the different meanings and implications of the commons that we have at present. These understandings have developed into an interdisciplinary approach (Laerhoven and Berge 2011) that now seeks to expand the understanding beyond the academic walls to incorporate the meanings of common practitioners through a different scientific paradigm called transdisciplinary research for strong sustainability (Dedeurwaerdere, 2014). That is where the epistemic regard and praxis of grassroots activists and commoners enter in scene. However, the need for a stable definition of the commons is not yet resolved (Benkler, 2013), neither by the legal school (Hess and Ostrom, 2007) nor by the political one, although it was indeed achieved by the economists what granted them a dominant position in the academic debate on what commons are and how they shall be governed and owned.

Therefore, having such a rich array of proponents and practitioners, the academic theory of the commons cannot be uniform, coherent or consolidated. Actually there are colliding theoretical approaches that underline tensions and fault-lines, but they basically reveal different epistemic regards to resources and practices that are essential to human societies and individuals. In the following sections, I will present the genealogies of the most relevant epistemic approaches to commons, tracing back the historical developments, the most relevant proponents and their definitions and typologies of commons. I will start by the one that became dominant in the XX century and beyond (the economic approach to commons), followed by the legal, historical, political and grassroots activists' schools.

\section{1.- The economic school of thought: intrinsic properties of goods}

\section{1.a.- The Neoclassical theory of public goods}

The economic school approached the commons by exploring the nature of the goods. In particular, the debate on the nature of public and private goods in the economic vocabulary can be traced back to the 1950s, with seminal texts by Paul Samuelson (1954) and Richard Musgrave (1959). However, the concept of public good and its role within political economy was previously mentioned by David Hume (1711-1776) and Adam Smith (1723-1790) ${ }^{9}$ and later developed by the German school at the beginning of XX century (Sturn, 2010). Actually, Richard Musgrave in his Ph.D. thesis and subsequent article in the Quarterly Journal of Economics (Musgrave 1939), drew already attention to the problem of collective goods that were not produced adequately in the market system because of different reasons. When Samuelson took up the concept in the 1950s, economists and the world at large favoured an active role for the state in the economy (Samuelson 1954, 1955) with Keynesian macroeconomics being at its peak (Desai, 2003).

Although Samuelson's mathematical definition based on two binary features (rivalry and excludability) is widely disseminated in non-nuanced models of public goods, the qualitative understanding of the specificity of pure public goods owes more to Musgrave's emphasis on the impossibility of exclusion

\footnotetext{
${ }^{9}$ Adam Smith already observed that some goods are regularly underprovided simply because profits cannot be recaptured by the suppliers of those goods. And when markets cannot provide such advantageous goods, governments should.
} 
(Demarais-Tremblay, 2014). In the original terms, Samuelson used rivalry ${ }^{10}$ as the main feature to divide goods into those of private consumption and those of public consumption. Rivalry refers to the extent to which the use of a good by one person precludes its use by someone else. A good that is nonrivalrous can be used by an additional person without reducing its availability to others. Samuelson also mentioned that the marginal cost of producing one additional item is zero: it does not cost anything when another non rivalrous good is produced and,in addition, one extra person consume the good. Later in that decade, Musgrave (1959) posited excludability (i.e. whether someone can be excluded from benefiting once the good is produced) and not rivalry as the relevant distinction between public and private goods. Samuelson agreed that rivalrous goods could be provided more efficiently by the markets whereas Musgrave defended the same for those excludable. In the same rationale, Cornes and Sandler (1994) argued several years later that non-excludability is the crucial factor determining which goods must be provided by the public sector. Non-excludability indicates that once a good is produced the benefits cannot be separated or appropriated by the producer/owner of the good and those individuals who do not pay for it cannot be excluded from consumption. Another way of understanding this concept is saying that adding an additional person to consuming the public good has a marginal cost of zero.

Pure public goods exhibit the characteristics of complete non-excludability and complete non-rivalry, while goods characterized by complete excludability and rivalry are termed private goods. Individuals can be prevented from using private goods by multiple exclusion mechanisms that may include enforceable property rights, physical barriers (fences, commercial secrets), excessive pricing or patents. Between those two pure extremes, a series of so-called quasi- or impure public goods are characterized by different degrees of non-excludability and non-rivalry. Figure 1 presents the two entry table hat classifies goods based on rivalry and excludability. These two properties that economists use to classify goods will be extensively discussed later on with regard to food. Additionally, Box 3 further elaborates on two additional categories that contributed to define and nuance the economic typology of goods, where common goods, in economic terminology, are included.

Figure 1: Four types of goods after the neoclassical economic school of thought on the commons

\begin{tabular}{|c|c|c|}
\hline & Excludable & Nonexcludable \\
\hline Rival & $\begin{array}{l}\text { Private Goods } \\
\text { Food and clothing } \\
\text { Car } \\
\text { House }\end{array}$ & $\begin{array}{l}\text { Commons Goods } \\
\text { Fish in open sea } \\
\text { Atmosphere } \\
\text { Public waterways }\end{array}$ \\
\hline Nonrival & $\begin{array}{l}\text { Low-congestion Goods } \\
\text { Cable television } \\
\text { Satellite radio } \\
\text { Online WSJ }\end{array}$ & $\begin{array}{l}\text { Public Goods } \\
\text { Tax-based: } \\
\text { Nuclear umbrella } \\
\text { The law } \\
\text { Indirect private funding: } \\
\text { Search engine } \\
\text { On the air TV }\end{array}$ \\
\hline
\end{tabular}

Source: Musgrave and Musgrave (1973)

\footnotetext{
${ }^{10}$ Non-rivalry was originally referred to as "jointness of consumption" in Samuelson's words.
} 


\section{Box 3.- The nuanced ontological categories: common and club goods}

The neoclassical theory, as originally proposed, seemed to be highly utopian, describing a non-existing world and rendering difficult to find appropriate examples that could illustrate well the typologies (public and private goods). Exemptions were the norm so a more nuanced approach to the theory had to be elaborated. Samuelson himself conceded (Samuelson, 1955) and Varian (1993) then took further that most goods do not exhibit excludability and rivalry in pure form: no good resembles the pure public goods of economic theory in real life. A significant number of public goods are non-excludable or non-rival only to a degree (Hampson and Hay, 2004). Therefore, other typologies for the so-called impure public goods were constructed, laying in the gradient between pure private and pure public goods (Holtermann, 1972). The so-called mixed goods were added to the neoclassical theory: "club goods", excludable but non-rival (Buchanan, 1965) (e.g. a toll road) and rival "common goods" (also called "common-pooled resources"11 or subtractable in Ostrom's terms) which are not purely non-rival but difficult to exclude from access and enjoyment (Ostrom and Ostrom, 1977; Ostrom et al., 1994: 4) (e.g. high sea fish).

Common goods are natural or human-made resources where one person's use subtracts from another's use and where it is often possible, but difficult and costly, to exclude other users outside the group from using the resource (Ostrom 1990: 337; Ostrom, 2009). They are formed by a resource system, the complete self-replicating and renewable stock (that can be considered as a public good) and resource units (that are more like private ones). Many common goods include food-producing resources such as fisheries, forests, tropical and alpine grasslands, wild game, seashore seafruits, irrigation systems and agriculture. Like public goods, common resources suffer from problems of "excludability" (i.e. it is physically and/or institutionally difficult to stop people from accessing the resource). Like private goods, they are also "subtractable" (or "rivalrous"), whereby the use of the resource by one person diminishes what is available for others to use (Robson and Lichtenstein, 2013) and they suffer from depletion through over-use and free-riding (Sands, 2003).

Actually, these type of goods were the main subject of the "tragedy of the commons" controversy (see in box 1 the contentious between Garret Hardin's and Elinor Ostrom's arguments). Across history and multiple societies, a great variety of institutions, legal systems, customary traditions and social norms have been set up to govern these common goods under multiple forms of common-property and openaccess regimes that have successfully endured until now, as perfectly described in practical and theoretical terms by Elinor Ostrom and the neo-institutional economists.

Club goods are those the costs and benefits of which are shared among and limited to a specific group of individuals, the so-called club. Hunting or fishing licenses or game reserves are food-related examples. Club goods can be either publicly or privately provided and often result in the creation of monopoly power. Sometimes club goods are provided by the public sector and funded either entirely through user fees or through a combination of user fees and taxpayer subsidization (e.g. public buses). Alternatively, private firms may provide the good or service with regulatory oversight to regulate the price as it has often been the case of the price of staple food.

\section{1.b.- Tenets of market-based life: The economic approach is partially theory and partially ideology}

The neoclassical theory defining public, private and common goods is grounded in the epistemic view of nature and society by the economists of the XX century (largely after the WWII and based on influencing figures such as John Locke, David Hume, Thomas Paine, Thomas Hobbes or Adam Smith),

\footnotetext{
${ }^{11}$ Actually, Ostrom (1990) started using the term "commons" to define common-pooled resources (forest, water, lobsters, seeds) but at the end of her career the term also included non-material goods (knowledge, computer codes) (Hess and Ostrom, 2007).
} 
and it cannot be disembedded from the dominant narratives and the political and economic systems that conformed the regime where the economists were working. In that sense the reductionist approach to nature (made of individual species or separated territories governed by sovereign states) and humans (rational and selfish individuals who seek to maximise their utilities) that was prevalent in the second half of $X X$ century is mirrored by the economic approach to private and public goods that has crafted the dominant narrative and lay people's understanding about the commons (Mattei, 2013a).

Most of the proponents of the neoclassical theory (Samuelson, 1954, Musgrave, 1959; Ostrom and Ostrom, 1977; Buchanan and Musgrave, 1999) use highly theoretical terms in a utopian market exchange whereby every human acts under the rationale choice principles ${ }^{12}$ having in every moment all the information needed to take the most adequate decision. These conditions are quite far from real-life human behaviour. Additionally, authors like Pickhardt (2002) observed that the production and consumption of private goods always involve externalities that affect us all. Those externalities (negative such as air pollution and positive such as global connectivity) are non-rival and nonexcludable thereby combining both public and private good characteristics. That would mean that most goods have mixed characteristics of private and public goods, and thus the theoretical distinction is rather artificial and highly hypothetical. That may explain why numerous economists, implicitly recognizing the fundamental flaws of the original definition, came up with additional explanatory terms and more nuanced typologies such as collective goods, club goods, social goods, public contract goods, common resources, impure public goods, semi-commons or merit goods (Musgrave, 1959; Buchanan, 1965; Demarais-Tremblay, 2014).

And yet, however dominant the economic epistemic narrative may be now, critiques have existed since the 90s. Several authors have criticized the economic approach as narrow, reductionist and an academic exercise devoid of any historical root or legal consideration, undervaluing those goods not capable of being allocated by monetised market transactions (Holcombe, 1997; Stretton and Orchard, 1994). Quoting more specifically, Samuelson's classic formulation was considered as "an austere simplification that produced a rarefied concept, a mythical beast, without any counterpart in, and therefore without any applicability to, the real world (Cornes and Sandler, 1994), "useless for policy purposes" and "pure theoretical fiction" (Desai, 2003) or "merely a scholastic exercise" (Musgrave, 1983).

Moreover, this economic theory of public/private goods has been misused to harm and discredit the commons as inefficient (Hardin, 1968) and backwarded (anti-modern) and hence justify the two only options that should be pursued: the legitimacy of government's public provision and power coercion and/or the enclosure of collectively-owned resources to become either state-owned or private-owned (Holcombe, 1997). According to Wall (2014), the stringent assumption of economic rationality together with methodological reductionism lead scholars to an oversimplification of commons analyses. The alternative narrative supplied by capitalism first and neoliberalism later posited the main tenets against the commons: market provision of goods is superior to commons-based systems or stateprovision (Sekera, 2014); humans behave like competitive selfish gene carriers (Dawkins, 1976) that seek to maximise self-interested utilities under a behaviouristic rational choice (Schelling, 1984); open commons management will be always sabotaged by free-riders (Olson, 1965; Hardin, 1968), absolute proprietary regimes in private hands shall be the most sacred right of all (Nozick, 1974) and individualism and property rights shall be the pillars of societal development, rejecting altruism and a welfare state (Rand, 1964). This narrative succeeded in becoming the hegemonic paradigm due to the historical circumstances that rendered it adequate to sustain the neoliberal phase of capitalism that was initiated in the 1970s and exploded after the end of the Cold War. Evidently, those proponents

\footnotetext{
${ }^{12}$ The theory of rational choice, as defended by Mancur Olson or James Buchanan: Individuals are short-term utility maximisers, rationale beings where irrational subjectivity does not play a role in behaviour.
} 
were systematically ignoring the importance of empathy, social relationships, embeddedness or culture to understand and interpret to existence and governing institutions of the commons.

\section{2.- The legal school of thought}

The legal approach to the commons is driven by the simple question: Who owns what resource? Or who has what legal entitlements to any given resource? Thus, the proprietary rights and the entitlements are the basis to define the commons. The legal proprietary regimes, being nothing but social contracts situated in specific times and places, have varied between societies, civilizations and historic periods within civilizations. In this section we will first undertake a short historical review of proprietary regimes since the Romans to understand how the commons were understood from the legal point of view.

\section{2.a.- The Romans understood well proprietary regimes}

In Western culture, the Romans established legal differences between goods that belong to individuals (res private or singularum), the State (res publica), everybody (res communis) and nobody (res nullius). Wild game or sea food used to be considered as res nullius whereas running water, the sea and seashore were res communis (Milun, 2011, chapters 2-3) ${ }^{13}$.

Nowadays, those legal typologies are still functional in many countries (Europe as a token) and the international legal regime although they are being relegated to oblivion by the market and state narratives and political doctrines based on Hobbes' and Locke's legacy (see below). For instance, this typology still exerts an important leverage on the political and legal approach to natural resources under no territorial sovereignty such as manganese nodules on the sea floor, the governance and sovereignty rights of the Antarctica, the oceanic fishing rights or the management and pollution rights of the atmosphere. Today fishes and wild games are still treated as res nullius, "no-man's resources" that no one owns in principle but they get owned once caught up or hunted. Water and air are however changing their legal consideration with the privatization schemes rampaging all over the world (i.e. exploitation schemes of underground water for corporations or carbon trade schemes to enable polluters to acquire rights to pollute everybody's air).

Regarding fish stocks, the customary Law of the Sea convention adopted the res nullius approach (a fish or seafood, while still alive and swimming, belongs to no one and it is only when captured that becomes absolute property of the fisherman) and yet, there are legal scholars that argued that fishes should also be viewed as res communis (i.e. Common Heritage of Mankind) and therefore protected and governed differently by an international body created for that purpose (Kent, 1978).

At present, the former res communis should be understood as resources belonging to all members of the community that could be ascribed to the public domain or the common heritage of mankind (Baslar, 1997). They should belong to all of us but we must first claim our rights to them, all of us. In modern legal doctrine, and in order to prevent the absolute privatization of every resource on Earth, former res nullius and res communis considerations should be granted special legal protection, since property is not a permanent thing but a relationship amongst people about things (Sider, 1980).

\section{2.b.- The founding fathers of modern property}

Private property refers to a kind of system that allocates particular goods to particular individuals to use and manage as they please, to the exclusion of others (independently from the need and from the

\footnotetext{
${ }^{13}$ See also the historical school section for an account of the influence of the Roman Law in current proprietary regimes.
} 
utility that others may obtain from the resource) and to the exclusion also of any detailed control by society. Though these exclusions make the idea of private property seem problematic, philosophers have often argued that it is necessary for the ethical development of the individual, or for the creation of a social environment in which people can prosper as free and responsible agents.

The idea of attaching certain duties to property had a considerable tradition in British normative thinking, and later on exerted a tremendous influence over European and American discourses. Thomas Hobbes (1588-1679) was still cautious about superseding proprietary rights to other fundamental rights for people to survive, since law's function was to protect all our fundamental rights. He said "if the law stood between an individual and the loaf of bread he needed to carry on living, then the law ceased to have meaningful content" ${ }^{\prime 14}$. Later in the century, John Locke (1632-1704) made property rights conditional to non-wastage of the good by stating that people should not enclose more land than they could work on. During the XVIII century, the foundational pillars of absolute proprietary regimes were masterminded by Hume, Smith and Paine. For David Hume (1711-1776), property (and justice) was an artificial idea, not natural or God's creation, created by humans since Nature itself never defined property. In that sense, Hume disagreed with Locke's view that private property was an extension of the self through the labour exercised on any natural resource, but he thought property regimes were nothing but a social construct. On the other side, Thomas Paine (1737-1809) classified property in two types: natural property, or that which comes to us from God, such as land, air, water, wild food; and artificial or acquired property, a human invention. The latter kind of property could be distributed unequally, but the first kind rightfully belongs to everyone equally. It is the "legitimate birthright of every man and woman, not charity but a right" (Paine, 1797). Finally, it was Adam Smith (1723-1790) who defined the normative principles of proprietary rights that were foundational to the very structure of society and they had to be enforced in all cases and under any circumstances. Indeed, absolute proprietary rights for individuals became the central supporting pillar of his ideas for a freemarket society (Smith, 1776). His thesis was that humans' natural tendency towards self-interest results in prosperity for all. Along those lines, unrestricted free trade, where everyone would aim at maximising their own profit, would promote greater prosperity for all than state-regulated mechanisms. His rationale was that collective public goods for the common good would be promoted through individual selfishness.

\section{2.c.- Locke: my own labour appropriates res nullius and res communis}

Nevertheless, the rationale that has exerted the biggest influence in modern property regimes all over the world is the labour theory of property elaborated by John Locke, also known as the principle of first appropriation. Locke in his Second Treatise on Government (Locke, 1690) justified individual ownership of part of the world resources (a God's gift to humankind), either land, water, food or minerals, by stating that when a person works, his labour that is personally own as part of his body enters into and improves the object subject of work and thus the mix object (natural commons plus personal work) becomes the property of the worker (Locke, 1690; Widerquist, 2010). This theory justifies the homestead principle, which holds that one gets permanent ownership of an un-owned natural resource (res nullius or res communis in Roman law) by working on it.

However, and that is very relevant, Locke also held that one person may only appropriate resources if "... there is enough, and as good, left in common for others" (Locke, 1690, chapter V, par. 33) ${ }^{15}$, what

\footnotetext{
${ }^{14}$ Actually, a legal provision defending bread-stealers stayed in place in many European countries since it was considered morally fair although not always legal.

${ }^{15}$ Locke posited "Nor was this appropriation of any parcel of land, by improving it, any prejudice to any other man, since there was still enough and as good left, and more than the yet unprovided could use. So that, in effect, there was never the less left for others because of his enclosure for himself. For he that leaves as much as another can make use of does as good as take nothing at all. Nobody could think himself injured by the
} 
is known as "the Lockean proviso" after another libertarian political philosopher from a different epoch, Robert Nozick (1974). Locke concluded that people need to be able to protect the resources they are using to live on, their property, and that this is a natural right. It is worth mentioning that Locke took for granted that the supply of essential natural resources (land, water, seeds, food) was virtually unlimited at his time with an entire America continent yet to be adequately exploited and vast areas of Africa and Asia to be explored.

However, Locke's doctrine should be subject to two additional provisos, after Timmermann's (2014) interpretation of Locke's treatise: firstly, the resources we mix labour with are unowned; secondly (the original provisio drafted by Locke), there is enough and as good left for others; and thirdly, retaining ownership is subject to avoidance of wastage. None of those provisios are satisfied in the current organisation of the industrial food system, so time has come to rethink the legal consideration of food as an absolute private good.

\section{2.d.- Modern legal evolutions of proprietary regimes}

After Thomas Hobbes, John Locke and Adam Smith, private property, individual freedom and autonomy will be melted together to yield the fundamental discourse to substantiate capitalism: only through individualism, absolute property rights and competition with others may anyone to thrive in life and achieve the proposed goals. Cooperating with peers and collective rights (features that characterize the Homo cooperans) are superseded by individual competition with own means (Homo economicus).

Following an interpretation of Locke's property theory, modern legal and political scholars translated the notion of having a "natural right" to enjoy the fruits of one's labour directly into having an "absolute right" to own, manage and destroy natural resources that are essential for human survival, namely food, water and air (Timmermann, 2014). Locke's narrative whereby individual property emerges as a natural consequence of one's own labour over a natural object was later on complemented with another utilitarian ideology: the absolute primacy of (a) proprietary rights over any other type of right and (b) markets over states. Private property and free markets are more efficient than collective or state property or governance (Alchian and Demsetz, 1973) and without the right of absolute alienation ${ }^{16}$ property is not well-defined and leads to inefficiency (Coase, 1960). The Coase Theorem ${ }^{17}$, although inapplicable to economic realities due to its high degree of abstraction and given hypothesis, was instrumental in re-affirming the usefulness of enforced private proprietary regimes. Subsequently, policies and legal frameworks were devised to protect, maintain and reproduce that specific narrative of property and market supremacy (Capra and Mattei, 2015). The emergence and consolidation of absolute private property rights for individuals is a story of evolutionary success (Coase, 1960; Demsetz, 1967), leading to more complex property regimes, and experimenting tragic trends along the whole process (Lopes et al., 2013). During the 70s and 80s, influential voices of the neoliberalism (Nozick, 1974; Rand, 1964) posited that respect for individual

drinking of another man, though he took a good draught, who had a whole river of the same water left him to quench his thirst. And the case of land and water, where there is enough of both, is perfectly the same".

${ }^{16}$ Absolute alienation is one of the five categories of proprietary rights that sets that you can do with a property of your own whatever you like to do it: prevent the other to have access to it, transfer your rights to anyone, destroy it for ever or make it disappear from the market (see Schlager and Ostrom, 1992).

${ }^{17}$ It is summarised as "as long as private property rights are well defined under zero transaction cost, exchange will lead to the highest valued use of resources". Therefore, private property is a key condition for market mechanisms to operate and non-absolute property rights hamper efficient market exchanges to reach a Pareto optimality. See: https://en.wikipedia.org/wiki/Coase theorem https://en.wikipedia.org/wiki/Pareto efficiency 
rights was the absolute standard and the only legitimate state is a minimal state that restricts its activities to the protection of the rights of life, liberty, property, and contract.

However, private property is not an absolute term that allows the owner to do whatever he/she wants with the owned good. Actually, it is very often found certain limitations in how far right holders are allowed to actively modify or destroy the object (Strahilevitz 2005). Although substantial liberties on how to manage the owned object are acknowledged, the multiple types of proprietary rights that can be found in the world on different types of resources has led to the idea that proprietary rights are a "bundle of rights" (Honoré, 1961; Schlager and Ostrom, 1992). According to those authors, property regimes are plural because these five bundles of rights are independent from each other and they can be combined in different ways with the three types of proprietary regimes: private property, state property and collective property (see Figure 2). Recently, reflecting on the plurality of historical developments of institutional settings governing natural resources, legal scholars developed intermediate categories such as semicommons (Smith, 2000).

Common property is a formal or informal property regime that allocates a bundle of rights to a group (Schlager and Ostrom, 1992). Such rights may include ownership, management, use, exclusion, access of a shared resource

a) Access: Right to enter a defined area and enjoy its benefits without removing any resource

b) Withdrawal: Right to obtain specified products from a resource system and remove that product from the area for prescribed uses.

c) Management: Right to participate in decisions regulating resources or making improvements in infrastructure

d) Exclusion: Right of participate in the determination of who has, and who does not have, access to and use of resources.

e) Alienation: Right to sell, lease, bequeath or otherwise transfer any or all of the preceding component rights

Figure 2: Bundles of rights in property regimes

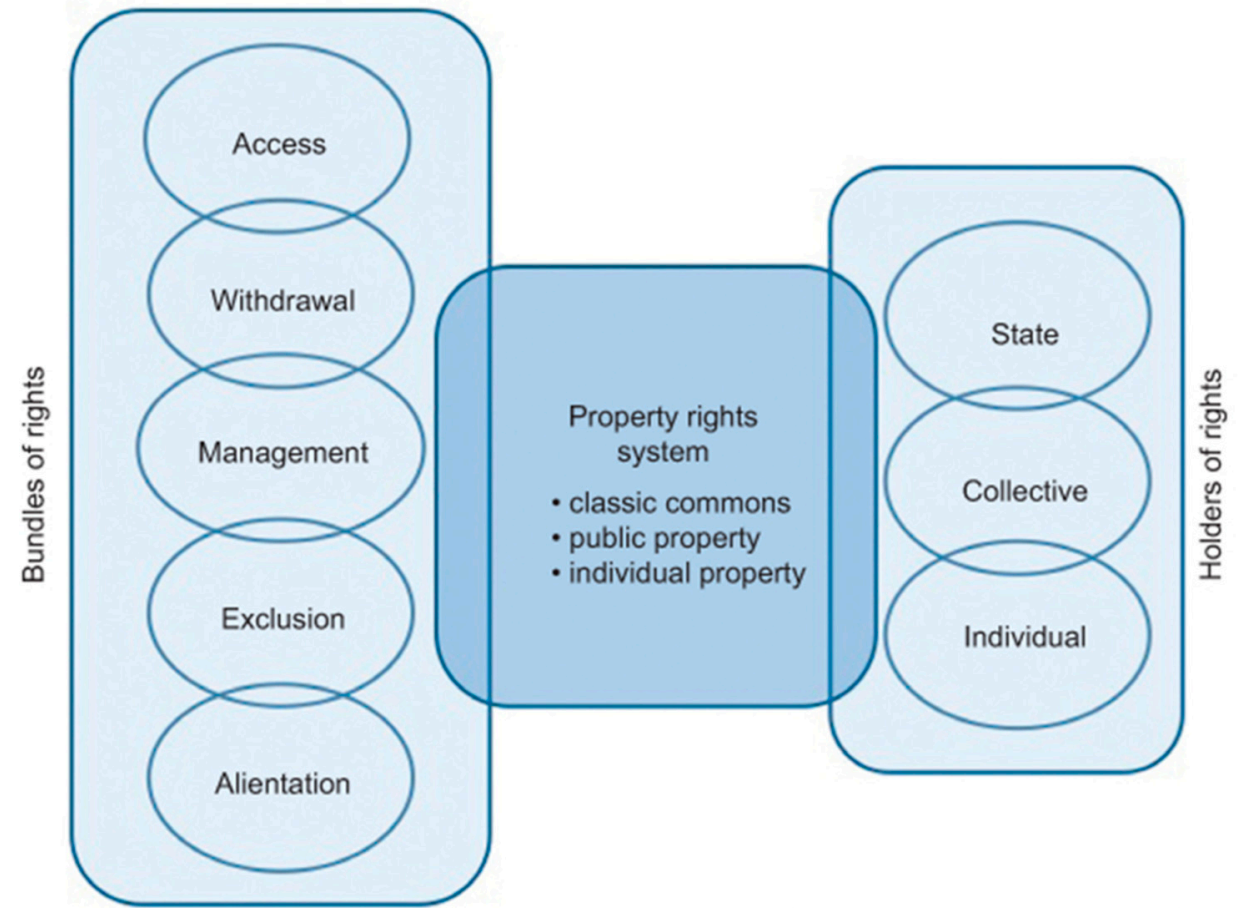

(Adapted from Schlager and Ostrom 1992; Barry and Meinzen-Dick 2008) 


\section{3.d.e.- The collective ownership struggles to exist}

As we have seen above, proprietary rights are not restricted to private individuals-entities or the state, although the realms of the State and the Market, after Hobbes and Locke, have monopolised the debate about ways of organising human lifes, resource management, food provision and the like during the XX century (Mattei, 2011). Since the Roman Empire, three type of proprietary regimes existed and they still exist: private, state and collective. The collective ownership can also be combined with collective governance, either/or or both together, and commons can also be found in private or stateowned land. It is often found that, in common lands, the owner's rights are somehow restricted and other people, usually local residents, pastoralists, walkers, have some rights over the land. These people are known as commoners. Commoners have some rights and entitlements over land uses and resources whereas the landowner retains other rights, such as rights to minerals, infrastructure construction or selling without changing commoner's rights to use. In a common property system, resources are governed by rules whose point is to make them available for use by all or any members of the society, regardless of who legally owns the resources. A tract of common land, for example, may be used by everyone in a community for grazing cattle or gathering food. A park may be open to all for picnics, sports or recreation. The aim of any restrictions on use is simply to secure fair access for all and to prevent anyone from using the common resource in a way that would preclude its use by others.

Collective ownership struggles to survive in spite of legal rules being a tool in the elite's hands to encroach, enclose, privatise and restrain access to the commons (Soto-Fernandez, 2014). However, legal regulations can also be turned into an instrument for defending the commons and its inhabitants from the encroachments of financialized commodification (Capra and Mattei, 2015), regulating and protecting the commons in many countries (Law of Goods in the Public Domain or Constitution art 132 in Spain or the Countryside and Rights of Way Act 2000 in UK). Actually, the protective power of the inclusion of the commons into Constitutional provisions is deemed essential by some scholars to sustain the long-term common good of societies (Mattei, 2013b). The commons owned by collective property and enshrined in legal frameworks are relatively protected from commodification, since they cannot be sold, transferred, alienated, mortgaged, divided or object of individualised possession. And so they express a qualitative logic, not a quantitative one. We do not "have" a commons, we "form part of" a common good, in that we form part of an ecosystem, of a system of relations in an urban or rural environment; the subject is part of the object. Common goods are inseparably united, and they unite people as well as communities and the ecosystem itself. Actually, commons can often be defined by the inappropriability. In other words, that appropriating something as one's private property is not permitted because that thing is reserved for common use (Dardot and Laval 2014: 583).

In that sense and more recently, progressive and engaged legal scholars are reinterpreting the commons through a different analysis of proprietary regimes. A good example to illustrate that is how privatisations are understood as stealing to every citizen his/her proportional share in publicly-owned commons that were created by nature or supported by public budgets and taxes (Bailey and Mattei, 2013), or how the Commission Rodota in Italy is seeking to protect legally the third type of proprietary regime based on collective ownership, and render it legally different from private and state property. Actually, there seems to be a wide array of legal innovations that commoners are inventing to build a new socio-economic order by constituting new rules and norms for their common production, governance and property modalities such as Land Trusts in US, squatting public places in Istanbul (Tarik square), Rio de Janeiro, Athens or Barcelona.

Table 1. Legally-based definitions of the commons

\begin{tabular}{|l|l|}
\hline Author & Definition \\
\hline $\begin{array}{l}\text { Simpson and } \\
\text { Weiner (1989) }\end{array}$ & $\begin{array}{l}\text { Commons are provisions provided for a community or company in common; also } \\
\text { the share to which each member of the company is entitled. }\end{array}$ \\
\hline
\end{tabular}




\begin{tabular}{|l|l|}
\hline Lessig (2001) & $\begin{array}{l}\text { A commons is any collectively owned resource held in joint use or possession to } \\
\text { which anyone has access without obtaining permission of anyone else }\end{array}$ \\
\hline Sandel (2009) & $\begin{array}{l}\text { A commons describe a specific resource that is owned and managed in common, } \\
\text { shared and beneficial for all members of a community }\end{array}$ \\
\hline
\end{tabular}

Summing up, for legal scholars a commons refers both to a physical good and the communal or collective proprietary rights governing it. See Table 1 for three legal definitions of the commons. Regarding types of property rights, they can be private (granted to individuals and legal entities and corporations), public (or state-owned) and collective property (legally recognized in many national and international legal frameworks). Most of current territorial commons are based on ancient rights, customary institutions, indigenous traditions or complex governance arrangements rooted in customary laws. A commons thus implies both "open access" and "shared participation" in the governance and benefits, outside of market and state mechanisms (Blackmar, 2006: 49-50), although collective property can be considered as a category of its own (Rose, 1986) or a type of private property.

\section{3.- The historical school of thought}

Considering the ideological and vocabulary discrepancies between different schools of thought on the commons, it is important to understand the commons from an historical perspective. Privatization, commodification and commons, like all historical concepts, require specification for each place in our own time (Friedmann, 2015). Historians focused on institutional developments such as E.P. Thompson, Karl Polanyi, Peter Linebaugh, Ferdinand Braudel, Massimo Montanari, Tine De Moor or Jose Miguel Lana-Berasain, to name just a few; the numerous authors that are regularly publishing papers in the International Journal of the Commons ${ }^{18}$ or those writing books on the commons such as David Bollier, Silke Helfrich or Derek Wall, they all study the political arrangements, narratives, institutions, legal frameworks and economic systems that actually existed (based on past reality facts interpreted by historians) around the commons, either termed as commons, common goods or common-pooled resources.

\section{3.a.- The commons have been rather common}

Historians have been analysing the commons, the collective management of natural resources for the benefit of the community, village or region and the different governing mechanisms that have been actually implemented by different social groups and civilisations to produce and distribute food since the very beginning of history as a scientific discipline. Departing from the idea that commons are compounded of a natural resource, often important for the community, and a set of collectivelyconstructed practices to regulate its production, access and distribution ${ }^{19}$, the historic regard to the creation, governance and disappearance of nature-based commons may inform the debate on current re-creation of commons and the struggles to defend the remaining ones.

The historical commons offer us a down-to-earth toolbox on how to organize the governance of important resources differently from the market mechanisms and state control, because all the

\footnotetext{
${ }^{18}$ https://www.thecommonsjournal.org/

${ }_{19}$ A definition nicely summarised by marxist historian Peter Linebaugh (2008) in his sentence "there is no commons without commoning". The commons do not just refer to the resource, material or immaterial, but to the resource plus the communing, the governed item and the governing community, the good and the people that decide that this good will be a commons, governed in a collective way.
} 
historical commons actually existed and many of them still endure, thus proving that we are not just imagining a chimera or pursuing a utopian dream ${ }^{20}$.

Forests, fisheries, land, water, food have all been considered, and still are, as commons in many countries and the consideration different civilisations have assigned to food-producing commons is rather diverse and certainly evolving. Food-producing commons are ubiquitous in the world, largely based on their abundance in historical times and the fact that different past and present enclosing movements have not been able to make them disappear...yet. Actually those communal lands, their collectively-governed resources and the institutions created to govern them (i.e. guilds, fraternities) played a pivotal role in rural development along history, providing essential resources for rural livelihoods. Common property may seem nowadays an anecdotic, backwarded or pre-industrial form of proprietary regime and governance, given the hegemonic primacy of private property, but for centuries the common property and collective governance of the commons were considered as efficient ways of managing natural resources (De Moor, 2015: 4).

While the economic definition of public-private goods only appeared in the 1950s, societies have been governing commons and providing public goods for millennia based on a mix of institutional settings including commons and private goods. The history of the commons in Europe can be traced back to the Ancient Greece (Macé, 2014), although commons and collective arrangements to manage them existed already since the formation of hunting-gathering societies (Henrich et al., 2006; Bettinger, 2015). However, it was not until the Roman Empire they were already enacted in the legal code. Thanks to the Byzantine Emperor Justinian, who between 529 and 533 A.D. mandated to compile all different Roman codes that were relevant to govern social life, certain commons (air, running water, the sea and the coastlines) were considered as res communes (shared things) in the body of law (Buckland, 1931: 91). The res communes ${ }^{21}$ can be used by all but acquired by none (Mears, 2008: 83 ) so they were legally protected from private enclosure and privatization. The Roman law set differences between the commons, the public goods (res publicae that are common to all and usually owned by the state) and those goods that belong to none now (res nullius) but can be owned in the future (wild animals, unexplored territories). After the dark period of the Early Middle Ages, the commons were recreated in Medieval Europe (XII and XIII centuries) based on territorial resources and new institutions that were designed to own and govern those resources collectively (De Moor, 2011). In the Middle Ages, competitive uses of lands between farming, pasture and woods were conflicting with each other due to demographic pressure and the first enclosure acts by kings and feudal landlords signalled the growing imbalanced between those resources owned and governed by private or state hands and those that were customarily owned and governed by communities, parishes, villages and tribes. Commons had a primarily economic function, sharing the risk to manage and produce essential goods for the survival of the community members, plus acting as a social welfare system and a source of communal bonds (De Moor, 2015: 2). This social function of the commons was especially important for women, who, having less title to land and less social power, were more dependent on them for their subsistence, autonomy and sociality (Federici, 2014). Later on, several waves of enclosures swept Europe's commons, being specially relevant those of XVIII and XIX century particularly important and well-studied in England (Neeson, 1993) and Spain (Lana Berasain, 2008).

\section{3.b.- Non-market based mechanisms to allocate resources were the norm in human history}

History scholars of the commons (Polanyi, 1944; de Moore, 2015; Illich, 1973; Mauss, 1970) have often underlined the importance of the embeddedness of economic institutions in the wider societal

\footnotetext{
${ }^{20}$ Additional information on the historical evolution of institutions for collective actions in Europe can be found in the following website run the University of Utrecht. http://www.collective-action.info/BIB Main

21 "By the law of nature these things are common to mankind-the air, running water, the sea and consequently the shores of the sea".
} 
configuration and the subsequent existence of alternative modes of exchange, such as gifts, reciprocity and redistribution, thus providing a counterbalance to the narrow economic school of thought (Laborda-Pemán, 2015).

In that sense, several authors have shed light on different means to allocate goods between humans (Fiske, 1991; Harvey et al., 2001; Karatani, 2014), perfectly applicable to our case on how to allocate food between producers and eaters. Although the market is undoubtedly a useful mechanism to distribute resources within human societies, it is neither the only one nor the most prevalent in all settings. Fiske's (1991) pioneering work already established four different allocation mechanisms found throughout history in different degrees, all of them still working in present times. Equality matching (or mutual obligation) was the most enduring mechanism for human societies for more than 1000 centuries of hunter-gatherers, and still surviving in tribal societies and children's behaviour. In parallel to mutual obligation between peers, there was another form of resource allocation called communal shareholding, where moral duties or natural habits are the basis for distribution with no expectation for return. For instance, food distribution within the family or closed groups, or food offered to guests. Here, Marcel Mauss' gift economy (1970) fits well ${ }^{22}$. Then, authority ranking was evolving as long as human groups were becoming bigger and more sedentary, and the redistribution roles were dependant on your position and power. Finally, the market pricing mechanism based on the equilibrium between offer and demand under specific rules of exchange and the state to govern the foundations of the market (enforcing contracts, currency parities, guaranteeing properties, etc).

In food-related examples, the typology developed by Harvey et al. (2001), although simpler in theoretical foundations, holds many commonalities with the other authors. Food can be provided by four types of agencies based on different principles: domestic (do-it-yourself or household provision based on family duties), communal (based on reciprocal obligations and norms), state (based on citizen rights or entitlements) and market (based on demand-supply market rules). By encouraging the development of non-market modes of food provisioning (state and/or communal), a more balanced and fairer food system can be rebuilt (Boulanger, 2010; Vivero-Pol, forthcoming b).

More recently, Karatani (2014) nuanced the modes of exchange in the following four typologies: a) reciprocity of the gift, where groups were either pooling resources (i.e. nomadic peoples) or establishing gift exchange mechanisms (as during thousands of years of the consolidation of stable agriculture in the fertile crescent; b) rule and protection, similar to Fiske's authority ranking, where initially feudal lords and later the state were collecting goods from servants and citizens in exchange of protection and good ruling; c) the current dominant commodity exchange mode, whereby money is exchanged for any another commodity under capitalism's specific rules. Finally, Karatani also foresees a fourth mode that would transcend the other three, a new post-capitalist value regime where we revitalize a sort of exchanging practices but modified by technological opportunities (webbased platforms and self-regulated local collective actions).

But the epistemic historical regard does not merely serve the purpose to show how frequent, disseminated and varied were the collective forms of governance of common resources and the nonmarket allocation mechanisms. A critical branch of historians, philosophers and humanities scholars have also analysed the rebranding process of goods from being socially, legally and politically considered as commons, to be firstly statised or privatized (the proprietary regime shifted from collective hands to the ruler's hands or state control), and ultimately commodified (meaning here as deprived of any other value that cannot be appreciated by the market, or where value-in-exchange obscures the value-in-use).

\footnotetext{
22 In the gift economy, governed by social norms and customs, goods are not traded, exchanged or sold but rather given without an explicit agreement for immediate or future rewards.
} 
In the early days of mercantilism and the consolidation of liberal states, one of the great conflicts that arose was precisely over the offensive against common goods, which was based on the belief that a lack of a clear sense of property implied a lack of interest in the sustainability of the goods or resources, a lack of interest that in the end would bring about their ruin, thus stunting general economic development. Indeed, the "open fields" of England or the "communal mountains" of Spain alike were effectively subjected to a heavy privatising pressure in the form of enclosures, ownership and division of land into plots. The commons were physically enclosed by fences, walls and wardens, and legally privatised by sophisticated copyrights, issuing permits, quotas, binding regulations, absolute proprietary schemes or taxation (Benkler, 2000; Young, 2003; Rocha, 2007; Lucchi, 2013).

The enclosure and commodification of essential goods or actions was identified by Karl Polanyi $(1944)^{23}$, Piero Sraffa (1960) or Michael Sandel (2013) as the dominant force in the XX century that sustained the rise of capitalism, the globalisation of the commodity markets and the financialization of every productive stream. Actually, many scholars concur with the statement that "the foundation of current neoliberal system is based on commodification of former commons-public goods". The prevailing view was that only privatisation led to growth. And that we would all benefit at the end of this economic growth (the so-called trickle-down effect). The ideal of "Homo economicus" was born of that criterion of economic/individual rationality, and liberal-capitalist logic was built on that foundation. However, the privatization of the commons crowded out other non-economic values and dimensions worth caring (Sandel, 2013). In this sense, history can often be used as a moral compass rather than an analytical tool in commons thinking (Jerram, 2015).

\section{4.- The political school of thought}

\section{4.a.- The consideration of anything as a commons is a social construct}

Initially, most political scholars during second half of XX century were aligned with the ontological definition of public goods manufactured by economists (non-rival and non-excludable) and thus usually understanding "public goods" and "commons" as inter-exchangeable terms (Severino, 2001), the former being mostly used in the political debates at national and international level and the latter being predominantly applied to natural resources governed by communities at local level. However, the last two decades witnessed a growing number of authors questioning whether the ontological and hegemonic definition of public goods given in neo-classical economics is adequate at all (Wuyts, 1992; Stretton and Orchard, 1994; Desai, 2003; Moore, 2004; Sekera, 2014; Dardot and Laval, 2014) proposing instead a socially- and politically-derived definition. They have argued that the extent to which a good is perceived as private or public does not depend as much on its inherent characteristics as on prevailing social values within a given society about what should be provided by non-market mechanisms (Deneulin and Townsend, 2007). Actually, the degree of excludability and rivalry depends not only on the nature of the good but on the definition and enforcement of property rights, regulations and sanctions, all of them political constructs. Society can modify the (non)-rivalry and (non)-excludability of goods that often become private or public as a result of deliberate policy choices (Kaul and Mendoza, 2003) as both properties are neither ontological to the goods nor permanent. This phenomenological approach to the commons is a main defining feature of the academic community of political scholar.

However, a customary understanding that equates commons with natural resources managed jointly still prevails in many academic circles. In this approach, the core element of the commons definition is the natural resource (either a forest, a pastureland, a coastal area or a river), usually a material good produced by nature although recently immaterial resources and situations have also being included,

\footnotetext{
${ }^{23}$ In what Karl Polanyi poetically described as the "revolution of the rich against the poor".
} 
namely knowledge, peace and genetic code. This approach identifies commons with the economic definition of common-pool resources, rival but not excludable, and by doing so accepts and departs from the reductionist economic definition of public goods and commons. And yet, for many other scholars, commons are not just things, resources or goods but self-regulated social structures, community processes and the consciousness and autonomy of thinking, learning, and acting together to govern a material or non-material resource for everybody's sake.

Along those lines, an important schism can be identified between a) those that approach the commons by understanding the nature and evolving characteristics of the resource to be governed and $b$ ) those that prioritise the governing community and its features (i.e. what is dubbed as "commoning") as the most salient identifier of commons. The former, evolving from the neo-classical political economy, seems to gather a constituency that sees no problem in reconciling commons with capitalism, sovereign states and the neoliberal narrative, whereas the latter sees "commoning" as a transformative and counter-hegemonic alternative to the profit-driven economic system termed as capitalism and the States that so wholeheartedly support it. The latter also sets differences between commons as human social constructs to be applied to material or immaterial resources from commonpool resources in economic terminology that are restricted to natural resources (Sekera, 2014; Dardot and Laval, 2014). In the next section, I will explore both political streams in detail.

\section{4.b.- Two political approaches to commons: resource- or governance-based commons}

The political school of thought on commons can be clustered in two opposing streams based on the primacy of the primary subject of analysis, either the resource or the governing community. Those who analyse the properties of the resource, although recognising that rivalry and excludability can be moulded by societal norms and technology, accept that commons are defined by those two features. The same features used to describe public goods. Actually, it is not rare to find within this constituency many scholars that use both terms indistinctly (a misunderstanding that will be addressed later on), being exchangeable terms, especially when dealing with Global Public Goods and/or Global Commons.

Transformative wise, those two streams present also another distinctive characteristic: the resourcebased scholars see the commons as self-regulated governing systems that can co-exist with current forms of free-market, private property regimes and absolute sovereign states (i.e. the proponents of the Global Public Goods). Conversely, the governance-based proponents conceive the commons as a transformative narrative enrooted in history but innovative enough to challenge the hegemonic duopoly formed by the neoliberal market and the state (i.e. Dardot and Laval, 2014; Capra and Mattei, 2015 or Wall, 2014), being this consideration shared with the activist's school to be explained later on.

In order to analyse the political approach to the commons, this section will dissect the different positions, namely the socially-driven consideration of commons based on resource properties or the alternative stance that posits that commons are defined by the "commoning" actions undertaken by self-organised communities.

Resource-based Commons can co-exist with neoliberal markets. The most influential group of political scholars in this stance are those who developed the theoretical approach to Global Public Goods (GPG), merging in this label the former economic categories of public goods and common goods (or common-pool resources). Global Public Goods, also termed as Global Commons (Buck, 1998; Brousseau et al., 2012), found their origins in two seminal books sponsored by UNDP (United Nations Development Programme) (Kaul et al., 1999, 2003), following the pioneering study of Kindleberger (1986). This concept, derived from the economic theory of public-private goods, called for a return to public action beyond national sovereign jurisdiction to highlight the need for greater cooperation across States in a global context of increased interdependencies, planetary threats and the appearance of a global citizenship conscience (Hugon, 2004). In other words, global commons-GPGs produce 
benefits that are available worldwide and across social strata. In political terms, a Global CommonsGPGs is a good with benefits that are strongly universal in terms of countries (covering more than one group of countries), people (accruing to several, preferably all, population groups) and generations (extending to both current and future generations, or at least meeting the needs of current generations without foreclosing development options for future generations) (Hjorth-Agerskov, 2005). They are universal in that all actors can benefit from their production; non excludable in that no actor can be denied their benefits; and non-rival in that the cost of a good does not go up with additional consumers (Burnell, 2008). They are the building blocks of different civilisations (Wolf, 2012). Therefore, they transcend national boundaries and require collective action for their provision or maintenance. Later on, an International Task Force on Global Public Goods was launched in 2003 to translate the theoretical concept of global public goods into a more practical tool for policy-makers. But actually, the movement that was meant to strengthen the idea of Global Commons-GPGs with feasible policy implications was finally weakening the narrative since it was including so many topics that ended up being termed at some point "a catch-all term to which people can attach anything they want" (Carbone, 2007) or "a buzzword, a term used for so many ideas that it threatens to become an empty concept" (De Moor, 2011).

Global Commons-GPGs cover a very large spectrum of global issues including fresh air, knowledge, global climate, the stratospheric ozone layer, outer space, Antarctica, high-seas fisheries, international waters, migratory wildlife, avoiding financial instability, the International Court of Justice, universal public health, social security and peace among others. Some of these resources, such as the global climate, have the economic characteristics of public goods: no state can be prevented from consuming them, and the consumption of such goods by one state does not diminish the amount available to others. Other resources, however, are clearly common-pool resources in the economic understanding. For these resources, such as fisheries, consumption by one state depletes the resources, leaving less for others.

The Global Commons-GPGs are created and paid for collectively because the profit-driven market will not produce them since there is no effective mechanism to privatise the resource or situation (i.e. clean air, weather data collection) or there are such significant positive externalities that society determines they must be available to all regardless of ability to pay (i.e. food, water, education, health or firefighters could qualify). For-profit market-based suppliers lack incentive to invest in producing the global commons either because a) their benefits are spread so broadly that their value cannot easily be captured by the seller and it is impossible to charge users individually b) or the return on investment is too uncertain (i.e. agricultural research).

Environment and climate may be the ultimate examples of a global commons, meaning something that is shared across borders, across generations, by all populations, and that all depend on to thrive (Kaul and Mendoza, 2003). Most global commons-GPGs global were originally considered as national public goods or local commons that, in the wake of globalization, have gone global. Commons-Public Goods are provided at national level by governments, such as public health, economic stability or the road network (Brousseau et al., 2012), and at international level they are naturally-produced (genetic resources, atmosphere, stable climate) or man-made produced (internet, financial stability), being regulated in some cases by semi-sovereign international institutions (i.e. the ISO (International Organisation for Standarisation) regulatory framework or the Codex Alimentarius).

The Global Commons-GPGs have been clearly embraced by the institutions that sustain the regime or the "institutional mainstream", thus proving their suitability to conform to the dominant narrative of capitalism and the lack of transformative power, considering their origins in the neoclassical economic doctrine of public goods. That explains why the Global Commons-GPGs have been included in the working programme of the World Bank (2013), the European Commission (EU, 2014), the Global 
Environment Facility ${ }^{24}$ or inter-governmental panels (ITFGPG, 2006). This understanding of global commons can co-exist perfectly with the current form of neoliberal capitalism, just requiring some international public actions, voluntary guidelines to corporate actors and minor adjustments in policies and international legal law.

Governance-based Commons as an alternative to capitalism. On the other side, for this group of engaged scholars, the commons are not about the nature of a good but about the governance regime for resources created and owned collectively (Workshop on Governing Knowledge Commons, 2014). By "commons" we do not mean things (rivers, forests, land, etc.), information or knowledge content, or places defined by their material properties, but rather a sense of doing things together because we need or want to do it for different reasons. It is commoning together what confers a material and nonmaterial common resource its commons consideration (Dardot and Laval, 2014). The primary focus of commons is not on resources but on interpersonal and human/nature relationships (Bollier and Helfrich, 2015) and therefore the human-made consideration of what is a commons requires specification for each place in our own time (Friedmann, 2015). Commons can be distinguished from non-commons by the institutionalized sharing of resources among members of a community (Madison et al., 2010: 841), what is often known as "commoning".

Commoning, as a form of governance different from the market allocation mechanism based on individual profit maximisation and the state governance based on command and control, demands new institutions, goal setting and forms of interaction, therefore being the bedrock to support a new moral narrative, a new transition pathway, a new economic model and a new relationship with Nature and the planet Earth. As commons implies a collective production of a good that is not up for private and individual appropriation (Dardot and Laval, 2014) and it means community governance, ownership and control (Bloemen and Hammerstein, 2015), commons are a system of decision-making, collective ownership and value-based purpose that defies the for-profit ethos of the market and the State's fundamental principles (delegated power, elite ruling for the common good, sovereign decisions). Commons are not about maximising individual utilities, selfish individualism or legitimated used of force, but about collective decisions, institutions, property and shared goals to maximise everybody's wellbeing.

This approach to define the commons based on the socially-constructed governing mechanisms is shared by many other authors coming from the activist school (Bollier and Helfrich, 2015b; Bloemen and Hammerstein, 2015) and the historical school (Linebaugh, 2008). Commons are nothing but selfregulated social arrangements to govern material and immaterial resources deemed essential for all that are place- and time-restricted and vary according to different societies, circumstances and technological developments.

\section{4.c.- An evolving historical construct with fuzzy vocabulary}

With the arrival of the capitalism ideology and the neoliberal decades (1980 until present) many public goods and commons that were still functional ended up being privatised. In any case, the social considerations of good and services are often evolving, being privatised or statised depending on needs, political circumstances and place-based determinants. For example, in USA fire services were once a business run for profit, but they are now a public service; meanwhile in Portugal, fire services have remained a voluntary contribution to society, not privatised until the recent austerity policies. Historically, schools or tutoring were available only to those who could pay and street lighting was purchased by wealthy pedestrians from lamp carriers. Moreover, the consideration of goods as public or commons vary from place to place: things that are public goods in one country may not be so in another. Health care for all has long been a public good in many European countries, Canada and

${ }^{24}$ https://www.thegef.org/events/our-global-commons-international-dialogue 
elsewhere, but not in the USA. And in Medieval Europe, hospitals were run and funded privately by churches, the Royal Court or charities, motivated not just by compassion but also by fear of infection and death (Cipolla 1973). Summing up, both commons and public goods are historical constructs ${ }^{25}$, which arise, above all else, from collective political decisions made on economic, technological, cultural, social and geopolitical bases specific to a particular period in history.

This epistemic school, contrarily to the rather precise terminology on commons, private/public goods and private/public/collective proprietary rights found in the vocabularies used by the legal and economic epistemic schools, is rich in fuzzy meanings and terms with a plurality of interpretations such as "the public good", "the common good", "commonwealth" or "public interest". The difficulties in differentiating the concepts of GPGs and Global Commons also illustrates this situation. Public goods or commons are different from the concept of "the public good" or "the commons good" which are ethical concepts and moral views of what is in a society's interest (Sekera, 2014). The public or common good is a collective ethical notion in political decision-making that may be interpreted in a utilitarian way as "to maximise the good for the maximum amount of people possible" or with a rights-based approach as "a set of minimum thresholds for everybody". This fuzziness in interpreting and using different terminologies for similar goods, or embracing terms for different goods, does not help in defining nuances and political implications of public goods and commons.

\section{5.- The grassroots and activists' school of thought}

\section{5.a.- Commons, an opposing narrative to capitalism}

This heterogeneous group is formed by social activists, urban and rural commoners and some engaged scholars that are simultaneously practitioners in common initiatives, and thus the epistemic regard on the commons is less consistent and more diverse. And yet, it is a common understanding within this school that capitalism greatly developed by enclosing the commons and privatising otherwise communal resources, owned collectively and governed by the community (Kostakis and Bauwens, 2014; Magdoff and Tokar, 2010), resources that Hardt and Negri (2009: 41) posited as "autonomously produced commonwealth". The neoliberal market system opposes to the mere existence of the commons because they represent an alternative regime for meeting needs and thus a threat to the hegemony of the market to allocate scarce resources to meet human needs (Bollier and Helfrich, 2015a).

This epistemic regard believes the current neoliberal economy has an inappropriate core DNA, since it combines a false belief in the infinity of material resources and endless growth with the belief that immaterial resources, which are actually abundant by nature, should be maintained artificially scarce either through legal (IP rights) and political means (i.e. seed policies banning distribution of local landraces not included in the official national catalogue in EU countries). Therefore, this constituency regards the commons and the free-market economy as colliding entities, and the commons-based transition narrative as an alternative to the neoliberal model (De Angelis and Harvei, 2013). However, the same author has underlined the paradox that existing commons are essential to both capitalist reproduction in its current form and the development of anti-capitalist alternatives (De Angelis, 2007). So, what sustains the unstoppable race to resource depletion led by the insatiable appetite of capitalism to profit maximisation and capital accumulation can also become its nemesis. The commons feed a counter-hegemonic struggle against the industrial and globalized neoliberalism and are an important element, not the only one though, of the emancipatory movement from the Homo

\footnotetext{
${ }^{25}$ The term "historical constructs" refers to sets that are moulded by the historical conditions (political, economic, technological, cultural) that render them unique. As social constructs, they are born in a particular society in a particular time period, live, evolve and finally disappear, either mutating, transforming or being forgotten.
} 
economicus paradigm (De Moor, 2013). They are called by Caffentzis (2012) as anti-capitalist commonists. Once you begin to take the commons seriously, nicely describes Le Roy (2015) "the whole edifice on which modern Western civilization is based, previously believed to be well-founded, collapses onto itself: the state, the law, the market, the nation, work, contracts, debts, giving, the legal personhood of private entities, private property, as well as institutions such as kinship, marital law and the law of succession, are suddenly called into question."

\section{5.b.- Defining a new narrative for sustainable and fair transitions}

The narrative and vocabulary of the commons is not being advanced by scholars, corporate interests or political parties, but by people doing things by themselves: a multitude of customary and contemporary commoners, practitioners and thinkers on the periphery of conventional politics. That narrative provides a sound alternative to the dominant neoliberal discourse but, contrarily to the latter, is still under construction in the innovative niches found in the margins of the dominant regime.

The practical commoners and theorists of the activist school reject the economic definition, based on rivalry and excludability, as reductionist or rigid (Helfrich et al., 2010) and they defend that any theoretical framework to understand the commons must learn from real-life practices and experiences of commoning in multiple context-based loci (Bollier and Helfrich, 2015). This group is re-creating a new narrative to define the commons, one based on vocabularies gathered from the other epistemic academic schools but filtered and validated through their daily practical actions as commoners.

Commoning is a radical concept because it insists upon the active and conscious participation of people in shaping their own lives, meeting their own needs and maintaining a shared purpose (Bollier and Helfrich, 2015a). In doing so, commoning and commons become thus political because they define the self-governing rules of a specific community and how this community is embedded in the larger landscape (natural, institutional). The commons trigger a moral economy different from the one that dominates market exchanges and the state-citizen social contract and they foster social connections, stewardship of resources and an escape from market culture. Commons are defined as a new political rationality that must replace the neoliberal rationality or even a different Worldview (Dardot and Laval, 2014: 572).

McCarthy (2005) highlights how the activist school of thought has only weak bonds with the economic and legal schools, or with their main subjects, namely common-pool resources and collective property regimes. The explanations may lay in the purported goal to surpass the reductionist views of those two epistemic regards, based on the ontological nature of the goods and legal property frameworks, to emphasize the relational "commoning" dimension (also present in one stream of the political school) and the freedom to decide what is a commons and how do we institute commoning practices over a common resource based on collective decisions

For this group, commons are a political movement that presents an alternative narrative, evidencebased policy options different form the dominant discourse and historical but efficient and resilient institutions that are neither market-based nor state-driven (cf. Mattei, 2011; Hard and Negri, 2009; Dardot and Laval, 2014). Furthermore, this school of thought is associated to critical approaches to the philosophical, political and epistemic pillars of absolute sovereign states and neoliberal markets.

\section{5.c.- How do commoners define their commons?}

Although traditionally the term commons has referred to natural resources, after the influential economic school, commons are richer and deeper. Actually, commons can arise whenever a distinct community chooses to manage a resource in a collective manner, with a special regard for equitable access, use and sustainability (Bloemen and Hammerstein, 2015). Value creation and stewardship in 
commons-based systems occur through the active participation of a community of people. In line with the political approach to commons, people's interactions to devise their own locally appropriate, agreed rules for managing resources that matter to them do create the commons. Along those lines, four definitions of commons by grassroots activists can be enlightening of this stream (see Table 2).

Table 2. Definitions of commons by grassroots activists and practitioners

\begin{tabular}{|l|l|}
\hline Bollier (2011) & $\begin{array}{l}\text { A commons arises whenever a given community decides that it } \\
\text { wishes to manage a resource in a collective manner, with special } \\
\text { regard for equitable access, use and sustainability. }\end{array}$ \\
\hline Helfrich et al. (2010) & $\begin{array}{l}\text { The Commons is a general term for shared resources in which each } \\
\text { stakeholder has an equal interest }\end{array}$ \\
\hline $\begin{array}{l}\text { Siefkes (2007) } \\
\text { Kostakis and Bauwens (2014) }\end{array}$ & $\begin{array}{l}\text { Commons are material and non-material goods which are jointly } \\
\text { developed and maintained by a community and shared according } \\
\text { to community-defined rules }\end{array}$ \\
\hline $\begin{array}{l}\text { Bloemen and Hammerstein } \\
\text { (2015) }\end{array}$ & $\begin{array}{l}\text { Commons refer to shared resources, the communities that manage } \\
\text { them, and the specific rules, practices and traditions that those } \\
\text { communities devise. They are goods that benefit all people in } \\
\text { society and are fundamental to society's wellbeing and people's } \\
\text { everyday lives, irrespective of their mode of governance }\end{array}$ \\
\hline
\end{tabular}

Those definitions often include an operational notion and a moral notion to define what a commons is. The operational conceptualization may put emphasis on the resource or the social practices around it (governance, institutions, customs), often dubbed as "commoning" 26 , a joint process to creating things together to meet shared goals. In any case, the resource becomes co-mingled with social practices and diverse forms of institutionalization, producing an integrated system that must be considered as a whole. For example, when applied to food, commoning may be sharing the art of hunting together (i.e. "monterias' - wild goat or board hunting by elite people in Spain or antelope hunting by pygmy people in Bostwana), sharing traditional rice landraces in China to combat diseases and pests (Hanachi et al., 2016), the social protocols of auctions of fish captures in Ireland, or all the traditions that express social belonging and solidarity in maize production, harvesting and religious rituals amongst the Guatemalan Mayas.

On the other hand, a moral notion would say commons refer to goods that are fundamental to people's lives and benefit the society as a whole, regardless of how they are governed. By being essential to people, commons morally "belong" to people (Bloemen and Hammerstein, 2015). The socially-driven definition of anything as a commons is first a moral decision that is subsequently regularised and legitimised by norms, traditions, legal frameworks or policy decisions. The activist movement for commons thus carries a deeper and subversive moral claim on who owns Earth's resources, questioning the underlying Locke's rationality to justify private property and appropriation of natural resources.

In a nutshell, material/non-material or natural/man-made commons are compounded of four elements for this school: (a) natural and cultural resources, (b) the communities who share the resources and (c) the commoning practices they use to share equitably, and d) the purpose and moral narrative that motivates and sustain the commoning practices by the community. The commons take a community and ecological perspective, what sustains its endurance through times, resilience to shocks and sustainability. This philosophy moves away from a purely individual rights-, market- and private property based worldview.

\footnotetext{
${ }^{26}$ For Silke Helfrich (2016), a conceptual leader and grassroots activist, commoning requires (a) maximal openness and transparency, (b) subsidiarity as a driving principle, (c) active use of deliberation and consent over consensus decision making, and (d) explicit commitment to steward commons and communities.
} 


\section{5.d.- Homo cooperans replaces Homo economicus}

The commons expresses a strong denial of the idea that society is and should be composed of individual consumers, utility maximizers or competitive selfish gene carriers, to use just three terms often used to dubbed the analytical construct of Homo economicus ${ }^{27}$. Commons and commoning also confront social Darwinism, the conceptual framework that applies Darwin's theory of species evolution to human relationships, paralleling the market, a social construct, with Nature. Social Darwinism sustains individualism, competition and conflict, and survival of the fittest. The dominant market morality tends to cast individualism as the ultimate fulfillment of autonomous humans and to denigrate collective activities as "inefficient" or "utopian", as if individual and collective interests were somehow mutually exclusive.

The commons breaks with this individualistic, mechanistic and competitive vision that has progressively transferred the idea of collective rights to individuals (i.e. human rights), collective ownership to private property, bundles of right over a resource to absolute right to sell and destroy and, finally, collaborative work to individual jobs. Instead, the commons discourse points to the possibility that people can live their lives as cooperative citizens, deeply embedded in social relationships, having a holistic and ecological view of the world, based on relationships of reciprocity, negotiated rules, cooperation and community.

Actually, many relevant scholars have posited that cooperation and reciprocity should be considered distinctive features of humankind (Aristotle, Mauss, 1970; Illich, 1973; De Moore, 2015; Bowles and Gintis, 2013) and a behaviour that humanity used to survive in this planet (Kropotkin, 1902 interpreting Charles Darwin). But this issue has long been contentious, between the defenders of competition or cooperation as fundamental driving forces of human behaviour and, hence, human flourishing. Already in Kropotkin's years, Thomas Huxley, a biologist, championed the Hobbes' philosophy (Homo homini lupus) that saw struggle, fighting, and competition as the most important tenets in the survival and evolution of human society. Kropotkin, based on extensive field research in Siberia, strongly objected to the Hobbesian notion that defined humanity as no more than selfish individuals that require an authoritarian State (Leviathan) to maintain peace and prosperity. He maintained that mutual aid was a factor that is both biological and voluntary in nature, and an enabler of progressive evolution.

\section{5.e.- Commons as a third way to organise society and govern resources important for humans}

Mainstream economists, political scholars and many practitioners have long assumed that there are really only two major avenues for governing things in an efficient way: the state control and provision and the market distribution mechanism (Bollier, 2010). And yet, other economists, such as Elinor Ostrom and the neo-institutionalists, showed with multiple examples that there are efficient and resilient ways to govern natural scarce resources other than the market mechanisms and the State regulations, namely the self-regulated collective actions to govern common pool resources (also shortly dubbed as the commons). Governing the commons proved to be efficient, productive and resilient (Ostrom, 1990). Commons-based governance is at work wherever people focus on a commons goal, whenever they share a vision and whenever they self-organize to get something done, invented or produced, whether that cooperation is modest and local or ambitious and global.

And this type of governance mechanism was not only applied to natural resources but it is also successfully applied to governing immaterial resources such as knowledge, software or democratic

\footnotetext{
${ }^{27}$ The ideal of Homo economicus is a psychological stereotype of human behaviour that posits that human beings are rational economic agents whose primary goal is to maximize individual utility, being this criterion of economic/individual rationality the foundation of the liberal-capitalist logic.
} 
tools in what is often termed as "Commons-based peer production" (CBPP). CBPP can be defined as any process whereby individuals can freely and openly contribute to a common pool of knowledge, code, design or hardware, necessarily coupled to trust, shared goals and participatory governance (no dependence between free contributors ${ }^{28}$ ) that creates a commons that is useful to all and open to new contributions. It is based on the mutualization of immaterial resources and the means of production ${ }^{29}$. This type of production mode on the Internet and computer programming can often out-perform the market in terms of creativity, efficiency, social satisfaction and political freedom (Benkler, 2006). In the food system, there are growing examples of open agricultural hardware communities such as AdaBio Construction in France, which share the design of agricultural machine designs for eco-agriculture, and similar projects such as the Slow Tools project ${ }^{30}$, Farm Hack ${ }^{31}$, the Open Tech Collaborative ${ }^{32}$, and Open Source Ecology ${ }^{33}$.

\section{5.f.- Converging old and new commons}

The renaissance of the ancient and marginalized commons (usually place-restricted natural commons in rural areas) and the invention of new ones (largely linked to knowledge commons or physical humanmade infrastructures) are initiatives triggered by the multiple crises our society is experiencing (economic model, governing model, environment) and therefore the commons are broadly perceived as a radically different narrative (grounded on different values and goals) and alternative pathway beyond the market-led solutions and the state-promoted policies.

This epistemic school is rather active, struggling to defend old commons from current modes of enclosure and commodification (land grabbing or privatisation of water distribution) or inventing new commons in the knowledge domain (Creative Commons licenses, internet) or in the cities (food councils, squatting squares or abandoned buildings to undertake community initiatives). Those activities and the accompanying narratives are part of a larger rejection of neoliberal globalizing capitalism and non-representative practices in current democracies. The theory and praxis of the commons within this constituency can be seen as counter-hegemonic and alter-hegemonic civic movements against capitalism and its worst formulation, the neoliberalism (Vivero-Pol, 2017).

\section{4.- Epistemologies of food}

This section unfolds how the different schools of thought have regarded food by using their epistemic tools (values, knowledges, vocabularies, ideologies) to produce multiple understandings, not often compatible. Actually, the dominant understanding at present is that food is not a commons, but a private good and a commodity instead, although historians, political and legal scholars, and grassroots activists can certainly disagree with this hegemonic considerations, based on non-economic epistemologies. The different rationales are presented in detail in the sections below.

\section{1.- The economic epistemology of food}

\section{1.a.- Revisiting the economic approach: social constructs can be modified}

\footnotetext{
${ }^{28}$ Peer production means that people cooperate voluntarily on an equal footing (as peers) in order to reach a common goal.

${ }^{29}$ www.boell.de/en/2014/07/08/commons-based-peer-production-introduction

${ }^{30} \mathrm{http}$ ://www.sustainablelivingproject.net/future-plans/community-store/ag-innovations

${ }^{31}$ http://farmhack.net/home/

32 https://opentechco.co/index.php?route=information/learnmore

33 http://opensourceecology.org/
} 
In strict economic terms, food is rivalrous. If I eat a cherry it is no longer available for others to eat. However, cherries are continuously produced by nature (wild cherries) and by human beings (cultivated cherries), so there is not a limited number of cherries on Earth. As long as the replenishment rate outpaces the consumption rate, the resource is always available and food is considered a renewable resource with a never-ending stock such as air. This renewal characteristic could play against the rivalrous consideration, as there should always be food on Earth, either produced by nature or cultivated. Food produced by nature and harvested in a sustainable way seems to be unlimited, available worldwide although not enough for all human beings. Therefore, the food I eat would not prevent others to eat food, although they could not eat the same piece I already ate. Actually, despite current adverse circumstances (rising world population, climate-related constraints to food production, exceeding planetary boundaries, over-exploitation of natural resources), the world is producing far more food than actually needed to feed adequately everybody and satisfying other nonconsumption uses, since one third of total food produced is wasted with no use and more than $40 \%$ of non-wasted food is meant to feed livestock and produce biofuels

Excludability means that it is possible for one person to prevent someone else from using the good. Excludability is usually determined by ownership or property rights (Sands, 2003), as the owner of a good can limit access to it. According to Ostrom, excludability is the ability of producers to detect and prevent uncompensated consumption of their products (Ostrom and Ostrom, 1977), but this feature cannot be applied to wild foods. In that sense, the debate on who owns nature-made wild food is rendered pivotal to understand the proprietary rights over food. Economists also point out that because of their non-excludability, public goods get under-produced or over-consumed and that idea fits well with wild food and human demand. The degree of excludability and rivalry depends on the technological nature of the good and the definition and enforcement of property rights. Theoretically speaking, food is also excludable as we can prevent anyone from getting access to food, either by physical means, by pricing it at unaffordable costs or by making it illegal to access food without paying a price (even when it would be thrown away anyway). However, should that food exclusion be enforced without reservations, that person would die of starvation, and thus it would eliminate the subject who tried to access the good, either private or public. In the next section, the normative reasons to prevent excludability with regards to food will be further elaborated. One could argue that currently most of food has a price in the market, and that price deters many people to freely access to food. Although this is true, it is a superb example of a social construction that can be modified by social norms: proprietary rights and the centrality of exchange value are nothing but a set of social and legal norms whose nature and specificities are determined by each society. Many societies have considered, and still consider, food as a common good (as well as forests, fisheries, land and water). At the same time, different civilisations and human communities have assigned to natural resources a connotation different from the one based on price tags and exchange of commodities. If the examples exist, it is therefore a matter of making them visible and thinking of new political and legal frameworks to recognize the common nature of food.

If food as a commodity is a social and legal construction, therefore the main features that traditionally have been assigned to food (excludability and rivalry) by the neoclassical economic school can be contested or at least revisited. Actually, several food-related elements (see table 3). In that sense, it is worth mentioning that both characteristics are neither ontological to the goods nor permanent, but mostly social constructions whose nature evolves along time and depending on societal norms. As evidence, there are plenty of cases where social actors have already modified the (non)-rivalry and (non)-excludability properties of goods so that they are enclosed or made available as a result of

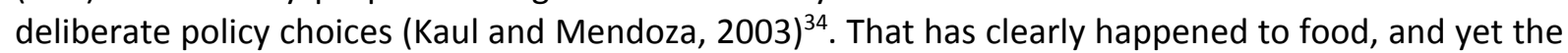
privatizing trend can be reversed and the rivalrous/excludable features of food can thus be modified

\footnotetext{
${ }^{34}$ See a further discussion in the next section of the political school of thought
} 
if the society so desires. In the next section, the excludability feature is modulated by moral considerations. Excludability is thus a normative property, not an ontological one.

Table 3. Food-related elements and its excludable-rivalry features

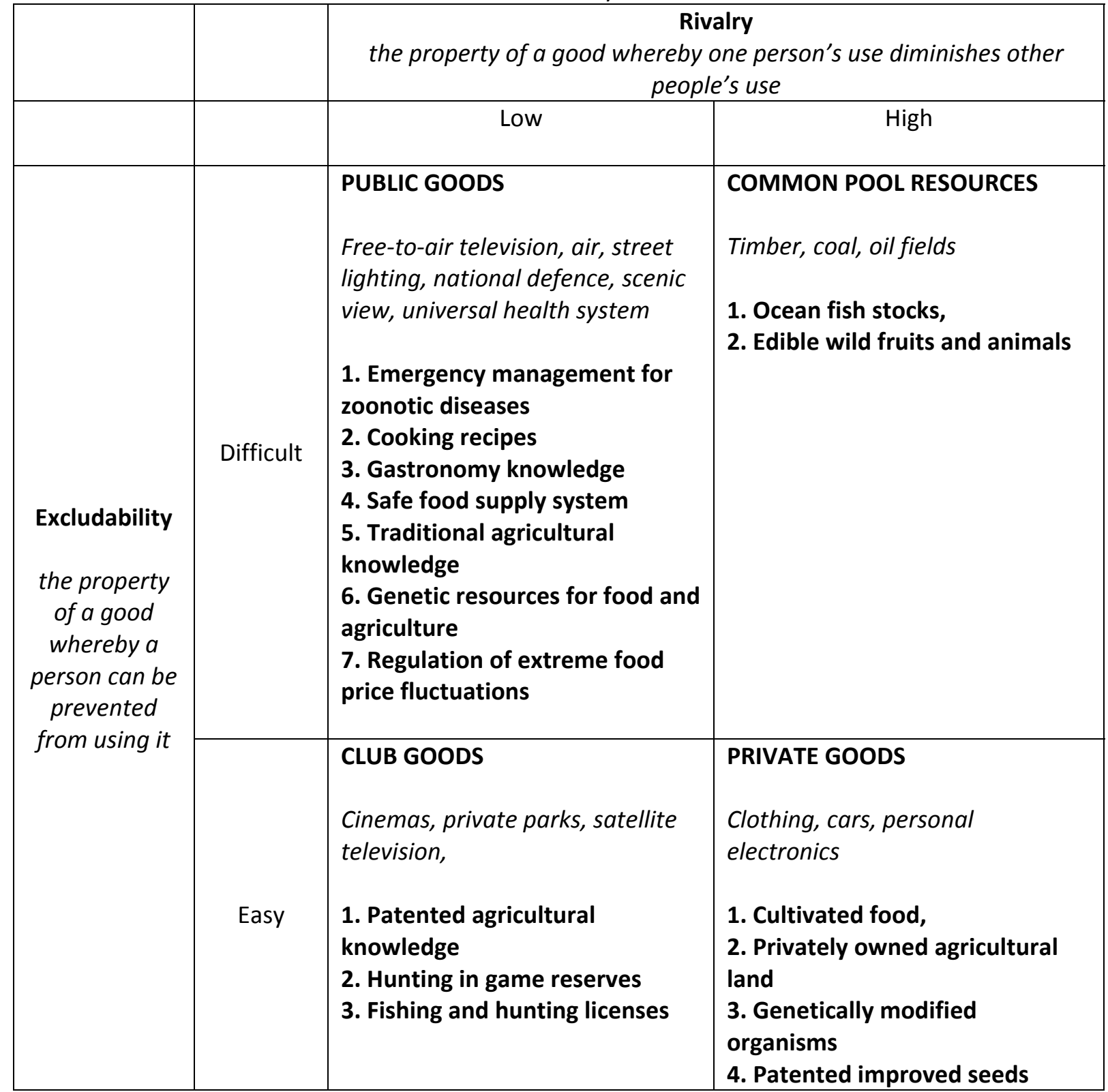

Note: The examples in cursive are coming from Hess and Ostrom (2007) whereas the examples in bold are food-related elements (material and non-material goods or services).

\section{1.b.- The normative non-excludability of food: between the economic ontology and the political construction based on moral reasons}

As we have seen above, public goods in the economic sense are goods from which access by individuals cannot be excluded. However, there is an ethical and political sense of the term 'public good' that needs to be distinguished here, invoking an important difference between "can" and "ought to": that is, a good is a public good anytime individuals "ought not" to be excluded from its use. This is the condition the philosopher John O'Neill (2001) rightly called "a normative public good". The economic and normative meanings are logically distinct. A good from which individuals can be excluded is not necessarily one from which they ought to be excluded. Actually, Light (2000), drawing on those distinct 
rationales, posited a distinction between public goods and publicly provided goods, where the latter refers to goods that ought to be provided as if they were public goods.

Following that rationale, the case against the consideration of food as a private good with absolute property and exclusionary rights should not be that food is not rival or excludable as cultivated food can easily be excluded from consumption (natural food is no so evident though) and it is indeed rival in that consumption. It is rather a case that it ought not to be excluded due to a number of reasons, being the most relevant its essential nature as a vital resource for the human body. With food being considered a private good, there are at present more than 800 million hungry people that cannot eat adequately because they lack monetary resources or food-producing factors, many of which need to be paid for (seeds, water, land, fertilizers, agro-chemicals, machinery). All the food has a price in the market and the state-run compensatory mechanisms to get access to enough to live are neither universal nor well-funded. In that situation, 165 million children under five are chronically undernourished and more than 3.5 million children die every year on hunger-related causes.

Food certainly qualifies as one of those goods whose consumption ought not to be excluded to anyone because that would mean firstly undernutrition and ultimately starvation to death. Consequently, food ought to be a commons, in the sense of being available to all, as it is essential to all and the sine quae non pillar of human life. The goods that any community defines as normative public goods from which members should not be excluded defines the relationships of need, care and mutual obligations that are constitutive of that community (O'Neill, 2001), since social norms may deny exclusive property rights over certain common goods. The arguments about the public provision of health or education are based on this type of social norms. Defining food as a good from which no member ought to be excluded is nothing but a political construct that helps defining which type of community, society and nation we want to be members of.

Furthermore, the ideas of food commons or food as a public good that are at odds with current mainstream thinking can also be justified by applying a nuanced approach to public goods developed by one of the founding fathers of the economic approach to public goods. Robert Musgrave (in Sturn, 2010: 304) insisted that public goods be "duly regarded as the conceptual basis for specific mechanisms of the public economy, entailing collective choices and the institution-based enforcement of their outcome". Actually, he accepted that public goods were a result of political decisions although Samuelson rejected that notion (Demarais-Tremblay, 2014). Adding to that debate another relevant and respectful voice, John Kenneth Galbraith (1958: 111) stated that public goods are "things that do not lend themselves to market production, purchase and sale. They must be provided for everyone if they are to be provided for anyone, and they must be paid for collectively or they cannot be had at all" (cursives are provided by author). In line with the political-economic dialectical debate, Musgrave (1959) introduced a new category of merit goods, defined as commodities that an individual or society "should have on the basis of needs", rather than ability or willingness to pay. Merit goods provide services which should apply universally to everyone in a particular situation, a view that Ege and Igersheim (2010) associates to the concept of primary goods found in Rawls (1971: 62) ${ }^{35}$. Examples include the provision of food stamps to support nutrition, the delivery of health services to improve

\footnotetext{
${ }^{35}$ According to Rawls (1971), primary goods are those goods supposed to be desirable for every human being, just as they are also useful for them ("every rational man is presumed to want"). Rawls, who divided them into natural and social, mentioned many good such as health, civil and political rights, income and wealth. Those primary goods were then the common base for his definition of the principle of justice. Quite oddly, he never mentioned essential resources for humans, such as food, water and air, although we cannot forget that Rawls was a political philosopher of liberal traditions, quite distant from Marxist or Keynesian positions.
} 
quality of life and reduce morbidity, subsidized housing and education. When consumed, a merit good creates positive externalities ${ }^{36}$.

\section{2.- The legal regard of food: common lands with food-producing commons}

This historical diversity mentioned above is reflected in the current world's richness of proprietary schemes over natural resources (Schlager and Ostrom, 1992) where different bundles of rights can be identified and assigned to specific food resources. The private arrangements that dominate at the industrial agriculture are not equally prevalent in other areas of the world, where subsistence, traditional and agro-ecological types of agriculture are the norm. Actually, in numbers, two billion people in poor, rural parts of the world still depend on the commons (forest, fisheries, pasturelands, croplands and other natural resources) for their daily food (Weston and Bollier, 2013), with over 2.6 billion living in and actively using forests and drylands, actively managed in commons or through common property arrangements (Meinzen-Dick et al., 2006). A great majority of small-scale traditional farmers still have mixed proprietary arrangements for food resources (Bove and Dufour, 2001), being the 500 million sub-Saharan Africans that still rely on communal lands just a token (Kugelman and Levenstein, 2013). FAO estimates that about 500 million hectares around the world are dedicated to agricultural heritage systems that still maintain their unique traditions with a combination of social, cultural, ecological and economic services that benefit humanity (Altieri and Koohafkan, 2007).

With regard to forests, over the last 30 years there has been an official transfer of tenure rights of forests to communities (amounting more than 250 million hectares) in Latin America, Africa and Asia (White and Martin, 2002; Barry and Meinzen-Dick, 2008; Sunderlin et al., 2008) resulting in slightly over $30 \%$ of all forests of the world being owned or managed by communities under legally-based collective proprietary schemes (Vira et al., 2015). The remaining land tenure of forest areas in developing countries is $61.3 \%$ administered by governments and only $8.7 \%$ administered and owned by private firms and individuals. This process of devolution (also termed as forest reform) is transferring different bundles of rights to local communities (represented by diverse constituencies, namely villages, ethnic groups, associations, etc) and has certainly confronted difficulties (Barry and Meinzen-Dick, 2008). And yet, national laws integrating customary land tenure are increasingly recognized at national and international levels (Knox et al., 2012). Actually, many forest areas often classified by national law as public lands are in many places actively managed by their inhabitants, very often through common property arrangements.

Moreover, in highly privatized and increasingly neoliberal Western Europe, despite centuries of encroachments, misappropriations and legal privatizations, common lands harbouring common resources (that can either be governed through collective arrangements or owned collectively) still amount more than 12.5 Million ha (EUROSTAT ${ }^{37}$ ), or $5 \%$ of EU land, although other estimates rises this figure to $9 \%$ when total land, including forest, mountainous and coastal areas managed and owned in commons, is considered (Brown, 2005 in Brown, 2006a). Although the current design of the EU CAP is dis-encouraging the maintenance of collective institutions to manage the commons (Sutcliffe et al., 2013), common lands represent $9 \%$ of surface of France (Vivier, 2002), 10\% of Switzerland, $7.1 \%$ of Romania (Sutcliffe et al., 2013), 5.4\% of Portugal (Serra et al., 2016: p. 172), 4.2\% of Spain (LanaBerasain and Iriarte-Goni, 2015) and 3.3\% of United Kingdom. European common lands are often pastures, grazing shrublands, forests, coastal stripes and mountainous areas with peaks, estuaries, beaches, riverbeds, lakes and marshes. Those commons, widespread, rich in biodiversity (Brown

\footnotetext{
${ }^{36}$ An externality being a third spill-over effect which arises from the consumption or production of the good/service

${ }^{37}$ With statistics only reflecting data from $13 \mathrm{EU}$ members and referring only to available agricultural land, not including forest or coastal areas.
} 
2006b) and strongly linked to family farming (Sutcliffe et al., 2013), may be owned by public bodies, private organisations or individuals and yet they are characterised by multiple and inalienable rights.

In United Kingdom, common lands are a mix of use rights to private property and commonly-owned lands $^{38}$. Local residents (called commoners) have often some rights over private land in their area ${ }^{39}$. Most commons are based on long-held traditions or customary rights, which pre-date statute law laid down by democratic Parliaments. The latest data indicate England has circa 400.000 ha (3\%) registered as common land ${ }^{40}$, Wales 175.000 ha (8.4\%) and Scotland 157.000 ha (2\%), what amounts 732.000 ha of United Kingdom ${ }^{41}$. Common lands in Spain, those owned by communities and not being part of state-owned territory, amount 2.1 million ha, according to the most accurate agrarian census. These lands, with more than 6600 farming households that depend entirely on them for earning their living, are grounded on legal principles that ensure the preservation of the communal condition of such property, as they cannot be sold (unalienable), split into smaller units (indivisible), donated or seized (non-impoundable) and cannot be converted into private property just because of their continued occupation (non-expiring legal consideration) (Lana-Berasain and Iriarte-Goni, 2015). The 1978 Spanish Constitution (Article 132/1) included an explicit reference to the commons, also defined in the Municipal Law of 1985. Ownership corresponds to the municipality or commonality of the neighbours and its use and enjoyment to the residents. In Galicia, Spain's autonomous region, there are over 2800 communal forests, owned by of neighbours, representing $22.7 \%$ of total surface total surface $(600,000$ ha). They are owned and managed by associations of resident neighbours ${ }^{42}$ inhabiting visigothic-based parishes $^{43}$, a legal figure recognized in the 1968, 1989 and 2012 laws $^{44}$ (Grupo Montes Vecinales IDEGA, 2013). Commoners get several inputs needed for small-scale farming such as feed for livestock, manure, cereals, firewood and medicinal plants and, lately, many wind generators have been installed in those lands, yielding additional revenues to the neighbours.

Common lands were pivotal for small farming agriculture throughout Europe's history, as they were source of organic manure, livestock feedstock and pastures, cereals (mostly wheat and rye in temporary fields), medicinal plants and wood (De Moor et al. 2002). Peasants pooled their individual holdings into open fields that were jointly cultivated, and common pastures were used to graze their animals. Their utility to human societies enabled them to survive up to present day and customary food initiatives based on common resources and non-monetized food values are still alive and closer to us than we think. However, the relevance of the socio-economic importance of the food-producing commons in Europe is hardly noticed by general media and hence neglected by the public authorities and the mainstream scientific research. And yet, they struggle to survive by being meaningful to the Europeans living nearby. Anyone can forage wild mushrooms and berries in the Scandinavian countries under the consuetudinary Everyman's Rights ${ }^{45}$ (La Mela, 2014; Mortazavi, 1997), the Spanish irrigated huertas (vegetable gardens) are a well-known and healthy institution (Ostrom, 1990: 69-81) and there are thousands of surviving community-owned forests and pasturelands in Europe where livestock are raised in free-range, namely Baldios in Portugal (Lopes et al., 2013), Crofts in Scotland, Obste in

\footnotetext{
${ }^{38}$ A good and well-known example is the 500 practising commoners in the New Forest, Hampshire.

${ }^{39}$ The Countryside and Rights of Way Act 2000 gave the public the right to roam freely on registered common land in England

$40 \quad$ http://webarchive.nationalarchives.gov.uk/20130123162956/http://www.defra.gov.uk/wildlifecountryside/protected-areas/common-land/about.htm [Accessed December 3, 2014]

${ }^{41}$ Author's estimate based on previous data. Northen Ireland has not been included in this estimate.

42 Those who have "open house and a burning fireplace" what means they regularly inhabit that house, either owned or rented. Therefore, commonality, as a proprietary entitlement to use common resources, is not inherited but granted by living in the community.

${ }^{43} \mathrm{http}: / /$ montenoso.net/wiki/index.php/MVMC/es [Accessed December 3, 2014]

${ }_{44}$ Law 13/1989 (10 October) de Montes Vecinales en Man Común (DOG no 202, 20-10-1989) and Law 7/2012 (28 June) de montes de Galicia.

45 Legislation in Finland (www.ym.fi/publications ) [Accessed December 3, 2014]
} 
Rumania (Vassile and Mantescu, 2009) or Montes Vecinales en Mano Comun in Spain (Grupo Montes Vecinales IDEGA, 2013). Finally, one current example can serve as memory of former flourishing foodproducing systems. In the medieval village of Sacrofano (Roma province, Italy), a particular and ancient Agricultural University (Università Agraria di Sacrofano ${ }^{46}$ ) still serves to local residents by governing 330 hectares of fields, pastures, forests and abandoned lands where the citizens residing in the municipality can exercise the so-called rights of civic use (customary rights to use the common lands).

Outside Europe, there are also documented examples of live and functional food-producing commons in current Fiji (Kingi and Kompas, 2005), Nigeria (Ike, 1984), the world-famous examples of US lobsterfisheries (Acheson, 1988; Wilson et al. 2007) or Mexico's Ejidos (Jones and Ward, 1998) just to name a few. In various other countries such as Taiwan, India, Nepal and Jamaica, land ownership of ethnic minorities is also granted as common land.

\section{3.- The historical consideration of food}

\subsection{1.- The food-producing commons are not new}

Historically, human societies have developed different institutional arrangements at local and regional level to produce, manage and consume food, whose major features were often an unstable balance between private provision, state guarantees and collective actions based on the commons (either land, water, forest, pasturelands, croplands, labour force). Food has not always been regarded as a pure commodity devoid of other important dimensions and it was cultivated for centuries in common and considered a mythological or sacred item. Many types of food are often endowed with sacred beliefs and their production and distribution are thus governed by non-market rules, being in many cases produce, distribute and eat in commons (Diamond, 1997; Fraser and Rimas, 2011; Montanori, 2006). Food-producing commons were ubiquitous in the world and history records are full of commons-based food production systems ranging from the early Babylonian Empire (Renger, 1995), ancient India (Gopal, 1961), the Roman Empire (Jones, 1986), the Inca Empire (see box), Medieval Europe (Linebaugh, 2008) and early modern Japan (Brown, 2011). Food was considered a commons as well as a public tool, with diverse and certainly evolving proprietary schemes ranging from a private good given for free to idle Temple priests, a resource levied by kings and feudal lords as well as a public tool used by Roman Emperors, Mayan dignitaries and the British Government to prevent disturbances and appease the revolting crowds (Jones, 1986; Schuftan, 2015; Kent, 2015). Food always carried many dimensions and it was never solely considered a tradable priced good.

\section{Box 4.- The Inca Empire: a food commons welfare state}

A rather interesting historical account relates to the Inca Empire, the largest empire in pre-Columbian America that lived between XIII and XVI centuries and occupied large territories in the current Colombia, Ecuador, Peru, Bolivia, Argentina and Brazil. The Inca economy was not based on a money system, and it did not have trade, being farming the economic mainstay. The government made sure that everyone had enough land or goods to survive taking care of the old and the sick and it managed the exchange of goods between faraway regions (Harris, 2007). In times of famine, the government storehouses were opened to the public so that no one would starve.

Instead of money, the Incas developed the mit'a labour scheme. The mit'a was a tax imposed on the common people by the Inca government by means of a labour requirement rather than a monetary sum. The head of every household was obliged to work on public projects (building monuments,

\footnotetext{
${ }^{46}$ The term "Università" derives from the ancient roman term "Universitas Rerum" (Plurality of goods) while the term "Agraria" refers to the rural area. http://www.agrariasacrofano.it/Storia.aspx [Accessed December 3, 2014]
} 
repairing roads or bridges, transporting goods) for a set period each year (McEwan, 2008). Using mit'a labour, Incas constructed irrigation canals and carved terraces from steep mountainsides, ensuring that all arable land was put to use to grow more food. Once surplus food was stored away, some of the people were able to quit farming and pursue other activities.

The Inca economy was unique among the ancient civilizations in that the government maintained control of almost all exchanges and took over all aspects of trade. Famine avoidance was a political goal in a rather hierarchical society where the nobility and elite had many privileges and private properties. Common people were not free decide over their lives and livelihood and yet hardly any state in antiquity allowed the peasantry such far-reaching social rights as did the Inca state (Katz, 1972).

This particular economic and societal arrangement prompted some scholars to call the Inca empire a welfare (McEwan, 2008) or socialist state (Harris, 2007). Although it is rather unhistorical to interpret past political systems with modern ideological paradigms, evidence points the Inca empire was optimized to prevent starvation rather than to foster trade (Newitz, 2012). And Chepstow-Lusty et al. (2009) suggested the hypothesis the Incas focusing their technological and cultural institutions around food production and land management, rather than market economies, to tackle climate fluctuations in a region where droughts and floods had likely wiped out a previous civilization known as the Wari.

The first wide-ranging enclosures of food-producing commons in Europe started in XVIII century, being especially intense during the XIX century due to the growing ascendance of the industrialisation and modernisation narrative that was eroding the customary moral economy that had largely prevailed all over Europe since early Middle Ages. Thompson (1993) excavated that moral economy, largely based on commons, customs and culture in England that were supplanted by the market economy and industrialisation in the XVIII Century. According to several authors, the replacement of traditional forms of agricultural land ownership and governance had few, if any, effects in increasing agricultural production or attaining greater efficiency or innovation (Allen, 1982; McCloskey, 1991), although they had immense distributional consequences (migratory movements and wealth inequalities). Nowadays, ample literature of historical and modern studies sustains the traditional food-producing commonpool resources systems were, and still are, efficient in terms of resource management as can be seen from their coherence and persistence despite the different enclosing waves (Ostrom, 1990; De Moor et al. 2002).

\section{4.- The political regard of food as a commons and a public good}

Although many natural resources, services and political achievements were included as examples of the Global Commons-GPGs literature ${ }^{47}$, little attention has been paid to the global commons related to agriculture and food security concerns (FAO, 2002), and actually food and nutrition security (FNS) was not even mentioned once. Since the Global Commons-GPGs stemmed from the economic definition of public goods (where food is plainly defined as a private good), no food-related natural resource or human-made service, situation or agreement was deemed to merit the consideration of GPGs. Only recently, some authors have started to elaborate rationales to justify why FNS should also be treated as a Global Commons-GPGs (Page, 2013; Vivero-Pol, 2015).

\footnotetext{
${ }^{47}$ The long list of GPGs proposed by some relevant references includes measuring standards, definitions of property rights, currency exchange rates and trade liberalisation (Kindleberger, 1986); international economic stability, international security, the global environment, humanitarian assistance, knowledge (Stiglitz, 1999); peace and security, the control of pandemics, natural public goods (the environment, biodiversity, climate), trade openness, international financial stability and knowledge (International Task Force on Global Public Goods, 2006).
} 
However, applying the reductionist economic rationality in strict terms, food can be considered as nonrival as long as the consumption rate does not exceed the production rate, what has been the case for many natural products up to mid XX century (Vivero-Pol, 2013). Moreover, based on moral reasons, food is a non-excludable good in the sense that no one ought to be excluded from their consumption or he/she would perish. It is therefore a Normative Public Good (O'Neill, 2001).

Food and Nutrition Security fits nicely with Kaul et al. (1999)'s definition of GPGs, namely "outcomes that tend towards universality in the sense that they benefit all countries, population groups, and generations". As everybody eats, no matter where, how and when, and disregarding gender, race, religion, political ideology or class, we can conclude that FNS for all shall be re-constructed politically, legally and economically as a commons-public good at national level, and a Global Commons-GPG at world level. In accordance with the political approach to the public good theory, FNS shall be provided to societies as a whole as it is on every body's interest and states and other relevant stakeholders such as private sector and civic movements have the obligation to do their best to do so. This idea was already suggested by Hans Page (2013) in a New York University working paper but it seemed to have a short trajectory and it was not echoed at all in international fora.

\section{4.a.- Food as a commons: essentiality and commoning define the alternative narrative}

Summing up, for many political scholars food can be regarded as a commons by the act of food commoning (producing, transforming and eating food together, based on multiple reasons not exclusively reduced to profit maximization). Food is jointly produced-transformed-distributed-eaten by different people, using different resources (many of them commons as well) and it is therefore a product of many hands, often eaten together since commensality is still the norm all over the world. This valuation of food as a commons is more evidently done at local level, in place-restricted rural and urban communities. Although the food commons are better expressed at local level, the underlying narrative can be expanded from niche to niche until the place-restricted meaning covers a broader area and a much greater constituency.

The risk of the public good approach to food lies in the top-down approach to governance from State institutions based on policies and laws (command and control type of politics) and the reliance in market-efficient services at the expenses of communities, people and alternative means of distributing resources. Food as a public good could be monopolized by the State, and people's participation could be neglected. So whereas legal institutions based on commons favour bottom-up initiatives of citizens to counter the traditional private sector-State divide and to respond to threats to our common heritage, the urgency to produce GPGs seems to justify a turn to new public-private partnerships and trust funds in development cooperation (Cogolati, 2016).

However, under a commons approach to food, communities are placed at the centre of the governing and stewardship process to manage and benefit material and non-material resources essential for their livelihoods. This approach basically recasts the traditional idea of development based on private property and wealth accumulation and brings to the centre reflexive democracy, participation, community-based development, rights-based approaches (i.e. food, water, clean air, land or seeds as human rights), indigenous rights, self-determination, right to communal ownership or rights of the peasants. This approach to consider food as a commons is consistent with Kallhoff (2014)'s different understanding of public goods as those that contribute to (a) social inclusion, (b) support the generation of the public, and (c) strengthen a shared sense of citizenship. Additionally, in the case of food, its essentiality for human survival adds another feature that supports its valuation as commons: food should be denied to no human. 


\section{5.- The grassroots activist's regard of food}

\section{5.a.- Grassroots and local food innovations are the revolutionary crowd}

The food system is complex and wicked, and there is an urgent need to combine multiple and partial solutions into a viable transition with shared values and multiple but convergent praxis. Alternative civic food innovations, either customary or contemporary, present multiple narratives to confront the dominant near-monolithic discourse of the industrial food system although they converge in having shared values about valuation of food dimensions and walking the talk on building alternative niches. This niches, yet unconnected but potentially nodes of discontent and struggle, can knit a crowdsourced alternative to the industrial mainstream. The diverse civic food innovations have in common the valuation of the food dimensions, other than its price in the market, the convivial aspects of food production, collection, preparation and consumption, and the peer participation on equal footing in designing, constructing and governing locally-embedded food initiatives. Moreover, the other's regard as caring about the others (either neighbour, community, city, region or planet) is a distinctive feature of well-nourished communities (Kent, 2015).

Local transitions towards the organisation of local, sustainable food production and consumption are taking place today across the world. Food is being produced, consumed and distributed through a multiplicity of open structures and peer-to-peer practices aimed at sharing and co-producing foodrelated knowledge and items. Civic collective actions for food are generally undertaken initially at local level with the aim of preserving and regenerating the commons that are important for the community. Three examples will serve to beacon this movement: the Food Commons in California, the Food Policy Council in Cork (Ireland) and the Walloon Network of Local Seeds (Belgium).

The Food Commons ${ }^{48}$ is an initiative launched by a group of scholars, activists and organic agriculture entrepreneurs from California to re-connect food production and consumption. The Food Commons has developed an alternative path to re-build different local and regional food systems where profit maximisation, lack of accountability and exploitation of common resources are not the norm. This initiative envision a re-creation of the local and regional food systems based on stewardship of common resources, community-based organizational and economic models, the science and practice of sustainable agriculture and the changes in food and agriculture values. Their main goals are the preservation of common benefit along the value chain and to achieve a sustainable, steady-state profitability. Institutionally speaking, the initiative encompasses a) a Food Trust (a non-profit entity to acquire and steward critical foodshed assets), b) a Food Hub, a locally-owned cooperative that builds and manages the Food Hub physical infrastructure and facilitates the logistics the food chain at different scales among all the parts of the system, and c) a Fund, a community-owned financial institution that provides capital and financial services to foodshed enterprises. Those three institutions are designed and governed by the people, the members of the Food Commons initiative.

Local food policy councils are mushrooming in Western countries (Scherb et al., 2012; Carlson and Chappell, 2015) and the Cork Food Policy Council ${ }^{49}$ in Ireland can nicely epitomises their goals and motivations. This city council is a partnership between representatives of the community, food retail, farming, fishing, restaurant/catering, education, environmental and health sectors and local authorities, that seeks to influence local food policy to improve equitable access to healthy food and to develop sustainable and resilient food systems. It evolved from a local experience, the Holyhill Community Garden, supported by the Cork City Council. The initiative enables people, eaters and producers, to re-gain control over the local food system, foster community conviviality and shared values around local, organic and non-commodified food.

\footnotetext{
${ }^{48} \mathrm{http}: / /$ www.thefoodcommons.org/governance/

${ }^{49}$ http://corkfoodpolicycouncil.com/
} 
Civic collective actions for food are mushrooming in Belgium in the last decade. They can largely be regarded as civic movements (i.e. AMAP - Associations to support Peasants' Agriculture or GAS Solidarity Purchasing Group) or social enterprises (i.e. GAC - Joint Purchasing Groups in Walloonia or Voedselteams - Joint Purchasing Groups in Flandre region), considering the importance given to social bonds between eaters or between eaters and food producers, and/or the importance given to food products and their accessibility. "Eating better", "improving local economies" or "transforming the food system" epitomize the three main attitudes behind the participation in those civic collective actions. As agents of change acting in innovative niches, their valuations of food seem to be correlated to their political stances vis a vis the dominant industrial food system: those who consider that being a member of an alternative food buying group has no political intention are split (50\%-50\%) between those who value food as a commodity or as a commons; whereas those who agree that being a member has a political intention rather value food as a commons (73\%) than a commodity (27\%). In brief, although being part of so-called alternative food movements does not mean to be a revolutionary, those who value food differently (as a commons) are more likely to act politically to transform the food system than those who value food as a commodity (Vivero-Pol et al., in prep).

\section{5.b.- Crowd-sourcing a transformational pathway with food as a commons, public good and human right}

However numerous, communicative and transformative those initiatives may be, the varied food innovations taking place in multiple scenarios (contemporary urban settings as well as customary rural villages) are not yet forming a self-aware alternative movement, but they are big and disrupting enough to present a strong alternative paradigm in the years to come, once they organise better as a connected polycentric web, recognise the different worldviews but defend their shared values and commonalities, being an essential glue the consideration of food as a commons (Vivero-Pol, forthcoming b). Those different "fields of struggle autonomously marching forward on parallel paths" will form the revolutionary crowd (Hardt and Negri, 2004) to confront the hegemonic corporate food system and its dominant productivist paradigm with the vindication of the commons (Dardot and Laval, 2014). The pursue of the commonwealth, common good or Buen Vivir (Gudynas, 2011) in a sustainable and fair manner will serve a catalyst for the active crowd to become a collective political subject, in a type of collective organisation known as technopolitics (Toret, 2013) or reflexive governance (De Schutter and Lenoble, 2010). And this new political actor, the many people acting in networked concert, will define the contemporary zeitgeist that will de-construct a vital resource, food, from its absolute commodification status towards a consideration of a commons.

The emancipatory food pathway will not be guided by one single agency of transition, be that Community Supported Agriculture, Food Policy councils, vegans, commoners, transitioners, organic consumers, zero kilometres customers, agro-ecologists, food sovereignty advocates or right to food campaigners, but a connected combination of different transformative agents of change that, while recognizing the nuances, priorities and particular praxis, will share the valuation of food as a vital resource, important for everybody's and Earth's health and survival, and therefore a public good, politically speaking; a commons, philosophically speaking; and a human right in legal terms. This minimum set of moral grounds, shared by a multitude of transformative agencies, clearly opposes the consideration of food as a commodity, the narrative elaborated and communicated by the industrial food regime. The alternative foodway will be crowd-fed by multiple actions with their own narrative and yet a core moral ground: food is not a commodity but a public good, a commons and everybody's right. 


\section{5.- DISCUSSION}

This chapter has unfolded the different genealogies and components of five epistemic approaches to commons (as resources plus governing practices) and how those epistemologies have understood food. The author considers five epistemic schools to interpret the commons, four restricted to the academic domain but whose narratives extend far beyond the academia and one encompassing the understanding of grassroots activists, practitioners of commons initiatives (dubbed as "commoners") and some engaged scholars. The defining features of each school of thought can be summarised in table 4.

For legal scholars, commons are usually place-restricted, determined by property entitlements. For economists, commons are determined by the inner properties of the resource. For historians, commons were a common way of organising resource governance and societal needs, and capitalism evolved to current status by enclosing and privatising everybody's commons. For activists and some political scholars, commons are created by the human-made praxis of collective governance and selforganised institutions. Therefore, the former epistemology that I subscribe posits that commons are neither types of resources with ontological properties, nor types of proprietary rights, but ways of acting collectively based on participation, self-regulation and self-negotiated principles and goals. And this praxis can be local, with clear physical boundaries as studied by Elinor Ostrom, or global, embracing the whole human race.

Table 4. Different epistemologies on commons and defining features

\begin{tabular}{|c|c|c|c|c|c|c|}
\hline \multirow{2}{*}{\multicolumn{2}{|c|}{ Typologies of commons }} & $\begin{array}{l}\text { Ontological } \\
\text { (resource- }\end{array}$ & \multicolumn{4}{|c|}{$\begin{array}{l}\text { Phenomenological } \\
\text { (community-based) }\end{array}$} \\
\hline & & \multicolumn{2}{|c|}{$\begin{array}{l}\text { Commons as } \\
\text { institutions }\end{array}$} & $\begin{array}{l}\text { Commons as } \\
\text { social } \\
\text { practices }\end{array}$ & $\begin{array}{c}\text { Commons as } \\
\text { universal } \\
\text { rights }\end{array}$ & $\begin{array}{c}\text { Commons as } \\
\text { transformational } \\
\text { politics }\end{array}$ \\
\hline \multirow{2}{*}{$\begin{array}{l}\text { Operational } \\
\text { (What commons } \\
\text { do) }\end{array}$} & Utilitarian & Economic & Legal & & & \\
\hline & Descriptive & & \multicolumn{3}{|c|}{ Historical } & \\
\hline \multirow{2}{*}{\multicolumn{2}{|c|}{$\begin{array}{l}\text { Normative (what commons } \\
\text { should do) }\end{array}$}} & & & Political & & \\
\hline & & & \multicolumn{4}{|c|}{ Grassroots Activists } \\
\hline
\end{tabular}

Note: the three typologies to classify commons are based on Van Tichelen (2015), Verhaegen (2015), Perilleux and Nyssens (2016), and Ruivenkamp and Hilton (forthcoming)

\section{1.- Different epistemologies lead to confusing vocabularies}

The different academic epistemologies (schools of thought) that theorized the commons have come up with multiple meanings for the same term and different normative valuations for similar resources. Since the commons are becoming a relevant academic and political topic in the last two decades (Berkes et al., 1989; Van Laerhoven and Ostrom, 2007; De Moor et al., 2016), these discrepancies among different academic epistemologies, and between the academic and non-academic constituencies, become politically relevant, since how to define what a commons is and how food can be valued are subjects of political debates.

As we have seen throughout the chapter, the vocabulary of the commons include different interpretations of the same resource (be that water, knowledge or food), different meanings for the same term, tensions between different epistemic schools with their own supporting values and fuzzy meanings for very common terms such as the "public good", 'for the common good" or "commonwealth". The diversity of approaches has produced a plurality of meanings for the same term. In table 5, different understandings by the five epistemic schools on five essential goods for humans 
are presented. One can see how the normative considerations (private, public, commons) are different, conflicting in some cases and certainly diverse and evolving. That points to the commonscommodity categories as rather phenomenological and always situated in place and historical periods (Mattei, 2012; Szymanski, 2016).

As a token, the term "Commons" may refer to (a) common-pool resources, understood as material goods in economic vocabulary that are rival in consumption but difficult to exclude (i.e. ocean tuna); (b) commonly-owned goods, material and non-material resources that are owned by a community, collective institution or group, and whose proprietary regime and entitlements differs from that of absolute private rights and state ownership (i.e. communal forests in Spain); (c) open free-access knowledge, that can be subject of open IP rights such as creative commons or copyleft licenses or it may belong to the public domain (i.e. cooking recipes or classic books); or (d) abstract desirable situations that benefit humanity (i.e. peace or universal health in political vocabulary). Finally, contradictory interpretations of similar resources can be found in the literature, with scholars defending that air is a public good and a commons because it is not rival and people cannot be excluded from breathing, and others arguing that air is rival because the oxygen in the air I breathe cannot be breathed by anybody else. The same applies to knowledge or seeds.

Table 5. Different epistemologies, confusing vocabularies on commons and food

\begin{tabular}{|c|c|c|c|c|c|}
\hline $\begin{array}{l}\text { Schools of } \\
\text { Thought / } \\
\text { Resources }\end{array}$ & $\begin{array}{l}\text { Historical } \\
\text { Describing } \\
\text { institutional } \\
\text { diversity } \\
\text { Phenomeneological } \\
\text { Commons existed as } \\
\text { place- and time- } \\
\text { restricted historical } \\
\text { institutions }\end{array}$ & $\begin{array}{l}\text { Economic } \\
\text { Based on rivalry and } \\
\text { excludability } \\
\text { Reductionists } \\
\text { Ontological } \\
\text { Commons (or } \\
\text { common-pool } \\
\text { resources) are } \\
\text { market failures }\end{array}$ & $\begin{array}{l}\text { Legal } \\
\text { Three types of } \\
\text { property and five } \\
\text { bundles of rights } \\
\text { Reductionists } \\
\text { Collective- } \\
\text { ownership can } \\
\text { be interpreted as } \\
\text { type of private } \\
\text { property or } \\
\text { category of its } \\
\text { own }\end{array}$ & $\begin{array}{l}\text { Political } \\
\text { Diversity of social } \\
\text { arrangements } \\
\text { created by people } \\
\text { Phenomenological } \\
\text { Co-existence of } \\
\text { commons \& } \\
\text { capitalism }\end{array}$ & $\begin{array}{l}\text { Activist } \\
\text { Struggle for old } \\
\text { commons, } \\
\text { inventing new } \\
\text { commons. } \\
\begin{array}{l}\text { Commons as } \\
\text { alternative to } \\
\text { capitalism }\end{array}\end{array}$ \\
\hline Water & $\begin{array}{l}\text { Commons } \\
\text { nullius) }\end{array}$ & $\begin{array}{l}\text { Private good being } \\
\text { commoditized }\end{array}$ & $\begin{array}{l}\text { Public-private- } \\
\text { collective } \\
\text { ownership with } \\
\text { different bundle } \\
\text { of rights } \\
\text { Human right }\end{array}$ & $\begin{array}{l}\text { Public good } \\
\text { (generalised) } \\
\text { although scholars } \\
\& \quad \text { countries } \\
\text { support } \\
\text { privatisation }\end{array}$ & $\begin{array}{l}\text { Commons, } \\
\text { public good and } \\
\text { human right }\end{array}$ \\
\hline Knowledge & Commons & Public good & $\begin{array}{l}\text { Complex public- } \\
\text { private- } \\
\text { collective } \\
\text { regimes } \\
\text { IP regimes in XX } \\
\text { century are } \\
\text { enclosing access }\end{array}$ & $\begin{array}{l}\text { Knowledge itself a } \\
\text { commons, but } \\
\text { physical } \\
\text { structures (seeds, } \\
\text { books) treated as } \\
\text { private goods }\end{array}$ & Commons \\
\hline Health & Private goods & Public good & $\begin{array}{l}\text { non-defined } \\
\text { proprietary } \\
\text { regimes }\end{array}$ & $\begin{array}{l}\text { public goods } \\
\text { provided by public } \\
\& \text { private means }\end{array}$ & Public goods \\
\hline Education & Private goods & Public good & $\begin{array}{l}\text { non-defined } \\
\text { proprietary } \\
\text { regimes }\end{array}$ & $\begin{array}{l}\text { public goods } \\
\text { provided by public } \\
\& \text { private means }\end{array}$ & Public goods \\
\hline Food & $\begin{array}{l}\text { Owned \& managed } \\
\text { by collective, public } \\
\text { and private entities } \\
\text { Diverse governance } \\
\text { A commons for } \\
2000 \text { centuries }\end{array}$ & $\begin{array}{l}\text { Private Good \& } \\
\text { Commodity }\end{array}$ & $\begin{array}{l}\text { Public, private, } \\
\text { collective } \\
\text { property regimes } \\
\text { Human Right }\end{array}$ & $\begin{array}{l}\text { Private good } \\
\text { provided by } \\
\text { private, public and } \\
\text { collective means }\end{array}$ & $\begin{array}{lr}\text { Owned } & \& \\
\text { managed by } & \\
\text { collective, public } \\
\text { and private } \\
\text { entities }\end{array}$ \\
\hline
\end{tabular}




\section{2.- The economic epistemology is hegemonic today}

Although we accept the commons have multiple meanings, narratives, vocabularies and supporting values, one school of thought has gained supremacy over the others in the second half of XX century: the economic epistemic regard. The economic approach to the commons became culturally hegemonic, in the sense that it became widespread beyond the economic academic milieu where it was conceived as a theoretical exercise, because it reached first a high degree of consensus within the discipline and, later on, it served the purposes of the ruling elite (policy makers and private entrepreneurs) to grow their entities (the state and the market) by encroaching and privatising the commons that belonged to people and communities. This approach, based on just the rivalry and excludability that are supposed to be inherent to the good, is theoretical and reductionists. The former because it is hardly difficult to find concrete examples where the two defining features are fully operationalised and the latter because it is evident that reducing the historical, political and legal complexity of commons created by people to just two features inherent to the resources represents an impoverishment of a rather diverse place-based time-dependent human construction. The resources, governing institutions, cultural trajectories, dominant narratives and moral principles that sustain the commons are all complex and fluent, as Elinor Ostrom taught us, so that distorting reductionism and overstated simple models shall be avoided (Frischmann, 2013). And yet, the economic meaning of commons is still dominant, as it was reinforced by other normative constructs such as the tragedy of the commons (Hardin, 1968), absolute proprietary regimes, private property as natural law, individualism, social darwinism, competition over cooperation as main driving motivation, and theory of rational choice. All of them have become the intellectual pillars that sustain the neoliberal socio-economic regime that is so hegemonic.

\section{3.- Commons are relational and transformational}

The concept of the commons is relational since it cannot be understood without the particular valuebased relations between the community and the resource and within the community itself (Helfrich, 2016; Verhaegen, 2015). Commons encompasses networking, bond-creation, social learning among citizens, empowerment, caring and emancipatory meanings through community praxis. Actually, as historian Peter Linebaugh said, the concept of commons is best understood as a verb. The commons are hence needed as a means to rediscover the embeddedness of the individual into society and nature (Clausen, 2016). Scholars, activists and practitioners get engaged in the praxis of old and new commons from an everyday life perspective in urban and rural settings (Walljasper 2010; Shiva, 2005). In that sense, Vandana Shiva points out: "each commons is also somebody else's commons", meaning that while a certain resource system belongs to a certain community, some of its elements also "belong" to others (both from the human and non-human world) beyond that community.

There are approaches to the commons that can be compatible with capitalist economies of unrestricted capital accumulation (neo-institutionalists or neo-hardiniens like Ostrom and her followers as mentioned by Caffentzis, 2012) and other approaches to commons are colliding with the basic foundations of capitalism such as the absolute primacy of individual property over other rights, the absolute sovereignty of the individual consumer over the collective wellbeing, the lack of limits to capital or resource accumulation and competition as the main driver of progress rather than cooperation (McCarthy, 2005; Hardt and Negri, 2009; Jeffrey et al., 2012; Dardot and Laval, 2014; Verhaegen, 2015). This represents the major schism between the dominant stream of political scholars and the grassroots activists. Commons are assembled by the aspiration to live beyond the commodification, privatisation and the market (Jeffrey et al., 2012) and that is why they represent a different entity, with different values, goals, narratives, ethical principles and functioning. In that sense, the commons are a competitor of the market and the state, a socio-economic conceptual and practical alternative to re-think the market economy and the public governance (Dardot and Laval, 2014) and therefore a different pathway to transit outside the multiple-crises momentum we live now. 
From the very moment that we accept the community has an instituting power to create a commons (resource, property regime, governing institution and purpose), we accept the community is bestowed with legal and political powers to regulate the resources important to them and thus commoning becomes transformational and certainly counter-hegemonic, since the State aims to retain those instituting powers of issues policies and enacting laws and the market its supremacy to allocate and govern scarce resources.

\section{4.- "Food is a commodity": plurality of meanings reduced to one}

This epistemic supremacy of economics, notwithstanding the plurality of meanings food is endowed with in different societies, civilisations and historical periods, has imposed its approach to food, despite other epistemic regards, such as the historical, legal, political and activist schools of thought, recognise that food can be valued as a commons, governed as a commons or owned collectively (see table 5). The iron law of economics that dictated the reductionist view of food as a private good that is better allocated through market mechanisms, with absolute proprietary rights and treated as a pure commodity, has become the commonly-accepted narrative since the 1960s, becoming now hegemonic due to the dominant role economics play in politics and societal issues.

The current situation that best explains the hegemonic narrative of the global food system is, adapted from Gramsci's Marxist philosophy as described by Bullock and Trombley (1999: 387-388), that a diverse society -with multiple proprietary regimes, multiple valuations of food and multiple political arrangements to govern food- is influenced by the economists' approach to goods -nowadays the influencing school of thought that informs the discourse in the ruling class- so that their reductionist approach to food -a narrative based on its rivalry and excludability-is imposed and accepted as the universally valid dominant ideology that justifies the social, political, and economic governance of the global food system as natural, inevitable, perpetual and beneficial for everyone, rather than as an artificial social constructs that benefit only the ruling class. Food as a private good and a commodity, as posited by the economists, is quite theoretical, reductionists and ideological; it has proven wrong to achieve a fair and sustainable food system, and prevents other food policies, based on alternative value-based narratives, to be explored.

\section{6.- CONCLUSIONS}

The thorough analysis and numerous examples provided in this chapter reveal that commons may have multiple vocabularies, being actually used in different contexts with different meanings. Those meanings (phenomenological) are then interpreted differently by researchers and practitioners with diverse epistemic regards (or the schools of thought as they are referred in this text). And yet, according to the neoclassical economic epistemology, goods are defined solely with respect to two intrinsic characteristics of the goods, a definition that is largely academic, reductionist, markedly ideological (constructing a theory that justifies capitalism first and neoliberalism later but with poor reflection in real-life economy and politics), highly theoretical (with numerous examples from real life that contradict the theoretical postulates) and certainly utopian (describing a non-existing world), and thus unfit to be directly applied to real life. Therefore, this particular approach is ontological ("goods are...") instead of phenomenological ("goods as...", "goods considered/valued/functioning as..."), what highly conditions future interpretations of the nature of the goods and determines the most suitable type of property regime and governing system to manage, allocate and use the resource. In that sense, the private goods are better governed by market systems and owned by private individuals with absolute rights. On the other side, public goods are assigned to governmental institutions since their huge externalities cannot be capitalised by private actors in a market system. There is also a hierarchy of allocation mechanisms and proprietary regimes: the market mechanism is superior to state governance, and private property excels public property. There is no place for a third way in the dominant discourse: collective ownership and collective governance are discarded as viable options to 
govern efficiently scarce resources. This ontological approach to goods has become dominant in the second half of the XX century when economics reigned as the dominant scholar discipline and allembracing explanatory epistemology (Vivero-Pol, forthcoming a). And still is now.

This economic epistemology has troubles understanding the commons as they profoundly challenge a foundational pillar of liberalism (the individual, rational and self-regarding freedom to act) and the subsequent evolution, in neoliberal terms, as the absolute sovereignty of the individual consumer to purchase. The commons regards the individual and the collective as nested within each other, being both equally important to frame the decisions, values and policy beliefs. Since commons can be sketched as a resource plus the commoning, they help re-embedding economics in the social context (local) and the natural environment where they are governed.

And yet, other epistemologies of the commons have shown that commons are plural, had and still have multiple meanings and forms of governance, governance arrangements for commons have plurality of goals (i.e. not just profit maximisation, but capped profits, social justice, intergenerational sustainability, resilience, minimum access to all), plurality of property rights and entitlements (I.e. no absolute primacy of the right to alienate a good), plurality of allocation mechanisms and not just the money-mediated free-market mechanisms based on value in exchange, and plurality of resources, independently from their inner characteristics.

\section{1.- The author's approach to food as a commons}

Finally, after having presented the variety of epistemic regards of commons in general and food in particular, I would like to present my own approach to commons and food as a commons. I support the social construction of any given material and non-material resource as a commons if we, human societies, so consider. Commons are forms of governance created collectively for resources owned collectively. This common arrangement is triggered by two important features: the essentiality of the resource to humans, and the desire to institute a collective governance of that resource where every person affected by the resource has a role in its enjoyment and custody. According to those features, food is essential to every human being (materially and spiritually), and it has been produced and distributed through non-market mechanisms for more than 2000 centuries, actually rendering it as a commons.

The definition of food as a commons contains a theoretical framework, an operational notion and a moral notion. The theoretical framework of food as a commons is based on the multiple dimensions of food to humans that have been reduced to six by Vivero-Pol (2017; forthcoming a; forthcoming b) for the sake of methodological appropriateness. Those dimensions of food as an essential resource, a cultural determinant, a human right, a public good, a natural resource and a tradeable good cannot be adequately valued by the market through the value-in-exchange (reducing to a monetary valuation the multiple meanings of food). Therefore, food cannot only work as a commodity but it has to be governed as a commons (with the human rights and public good dimensions becoming quite relevant).

The operational conceptualization however put emphasis on the social practices around foodproducing systems (governance, institutions, customs). Commoning is the action of cultivating, processing, exchanging, selling, cooking and eating together. For example, when applied to food, commoning may be sharing the art of hunting together (i.e. "monterias' - wild goat or board hunting by elite people in Spain or antelope hunting by pygmy people in Bostwana), sharing traditional rice landraces in China to combat diseases and pests (Hanachi et al., 2016), the social protocols of auctions of fish captures in Ireland, or all the traditions that express social belonging and solidarity in maize production, harvesting and religious rituals amongst the Guatemalan Mayas. 
On the other hand, a moral notion entails that food is a commons because it is, undeniably, fundamental to people's lives and a cornerstone of human societies, regardless of how it is governed or who owns it. By being essential to people, the food commons belong to people and shall be governed by them. In that sense, considering food as a commons carries a deeper and subversive moral claim on who owns Earth's food and food-producing resources (water, land, seeds, agricultural knowledge), questioning John Locke's rationality to justify private property and appropriation of natural resources.

The food commons are thus compounded of four elements: (a) the natural and non-material resources (foodstuff, cooking recipes, traditional agricultural knowledge), (b) the communities who share the resources (local, national or global because we all eat), (c) the commoning practices they use to produce, transform and eat food and d) the moral narrative that sustains the main purpose of the food system: produce food sustainably to feed the people adequately. Any food commons benefits from a relational approach between the good, the purpose to use that good, the community that agrees on that purpose and the governing mechanisms to achieve that purpose.

The commodification of food that became a global mantra of the industrial food system has neglected the value-in-use of food (the nutritional and cultural qualities that render a natural resource an edible product) and it has been replaced by a monetized value-in-exchange, where empty, cheap but tasty calories of ultra-processed food that fulfils the food safety standards have replaced nutritional, healthy, organic, tasty, locally-embedded and freshly-cooked meals. The original purpose of food (meeting human caloric needs) has been distorted by an ever-increasing share of food allocated to feed livestock, machineries and pharmaceutical products. The entire community of food producers and eaters has been evicted from the governance mechanisms that dictate the legal frameworks, policies and financial support of the global food system. Thus, the eaters can only exert a decision making power as customers that purchase a cornucopia of processed food supplied by a shrinking group of transnational food corporations. And food producers, especially the small ones in the Global South, are prone to become food insecure because they cannot raise enough money with their production to purchase enough and appropriate food to satisfy their needs. So, the purpose of the entire food system (producing food for all in a sustainable way) is not achieved at all.

In that sense, I propose to use the best epistemic tools of each school of thought to understand food as a commons (by the eaters and producers), to be treated as a public good (by the governments) and as essential resource that has to be traded under specific restrictions (by the private actors). The economic school of thought shall replace its ontological consideration of an essential resource with a tradeable dimension for a phenomenological understanding where the value-in-use can fine-tune with the value-in-exchange. The legal school of thought can accept that multiple proprietary regimes and entitlements are valid and functional when food is at stake. The political school of thought should legitimise different governing mechanisms for an essential resource for human and societal survival other than market-based allocations, and can devise particular arrangements for civic food actions, public policies and moral economies to co-exist. The historical school of thought has proven that those non-market mechanisms have actually existed in many places for centuries, and the current market primacy and commoditised regard of food is just a very exceptional consideration spurred by the neoliberal ideology so pervasive in economic and non-economic domains today. Finally the grassroots activists school of thought reminds us the ultimate purpose of a successful food system is to feed us all within planetary boundaries and not mortgaging the food-producing resources of future generations, what is currently and sadly not the case with the dominant industrial food system.

The practice of the commoning has instituting power to create laws, to review the existing ones and to set a different legal and political institutional framework (Charbonnier and Festa, 2016; Dardot and Laval, 2014; Capra and Mattei, 2015; Ruivenkamp and Hilton, forthcoming). And that is what actually frightens the most to the consolidated duopoly in the industrial food system (the state and the food 
market): self-organised communities and social food movements, based on different narratives and moral grounds (i.e. food as a commons or a public good), may design governing and allocation mechanisms and legal frameworks different from those that maintain the globalised free market of food and the state and multi-state institutions (i.e. WTO, Committee of World Food Security). Recommoning food systems may attack the legal and political scaffoldings that sustain the hegemony of the market and state elites over eaters (all) and food producers (more than 2 billion). Being so convivial, relational and important for individuals and societies, food is a perfect agent of change (McMichael, 2000) with transformative power (Vivero-Pol, 2017). Re-commoning food may help us re-creating sustainable forms of food production (agro-ecology), new collective practices of governance (food democracies), and alternative policies (food sovereignty) to regain control over the food system by the most relevant actors (eaters and producers) from the current dominant actors (agri-food corporations and governments). Actually, the re-construction of the entire food system as a commons is a revolutionary idea defended by some Italian scholars (Pettenati and Toldo, 2016; Ferrando, 2016).

History taught us that food has been valued and governed as a commons for centuries in different civilisations, and legal and political scholars demonstrate this consideration is still alive in many customary food systems and it is being reconstructed in innovative contemporary food initiatives. So, considering food as a commons is not a no-place (wrongly interpreted from Greek oú "not" and tóroৎ "place"), but a good place to aspire (derived from Greek عũ "good" or "well"), the final goal of a different transition pathway that takes us from this unsustainable and unfair food system towards a better one where everybody can eat well three times per day because food is not just governed as a commodity. 


\section{BIBLIOGRAPHY}

Acheson, J.M. (1988). The lobster gangs of Maine. University Press of New England.

Acheson, J.M. (2003). Capturing the commons: devising institutions to manage the Maine lobster industry. University of New Hampshire, Lebanon, $\mathrm{NH}$.

Aguilera-Klink, F. (1994). Some notes on the misuse of classical writings in economics on the subject of common property. Ecological Economics, 9(3): 221-8.

Alchian, A.A. and H. Demsetz (1973). Property right paradigm. Journal of Economic History 33: 16-27

Allen, R.C. (1982). The Efficiency and Distributional Consequences of Eighteenth Century Enclosures. The Economic Journal 92: 937-953.

Allouch, N. (2015). On the private provision of public goods on networks. Journal of Economic Theory, 157: 527-552

Altieri M.A. and P. Koohafkan (2007). Globally Important Ingenious Agricultural Heritage Systems (GIAHS): Extent, significance, and implications for development. FAO, Rome. http://www.fao.org/docrep/015/ap021e/ap021e.pdf. (accessed on 3 April 2017)

Appadurai, A. (2005). Commodities and the politics of value. In: Ertman, M.M. and J. C. Williams, eds. Rethinking commodification. Cases and readings in law and culture. New York: New York University Press. Pp. 34-45.

Bailey, S. and U. Mattei (2013). Social Movements as Constituent Power: The Italian Struggle for the Commons. Indiana Journal of Global Legal Studies 20(2): 965-1013.

DOI : 10.2979/indjglolegstu.20.2.965

Barry, D., and R. Meinzen-Dick (2008). The Invisible Map: Community Tenure Rights. Paper presented at the 12th Conference of the International Association for the Study of the Commons (IASC), Cheltenham, UK, 27 pages.

http://iasc2008.glos.ac.uk/conference\%20papers/papers/B/Barry_138902.pdf

Baslar, K. (1997). The Concept of the Common Heritage of Mankind in International Law. The Hague, The Netherlands. Kluwer Law International.

Benkler, Y. (2000). From consumers to users: Shifting the deeper structures of regulation toward sustainable commons and user access. Federal Communications Law Journal 52:561-79.

Benkler, Y. (2006). The wealth of networks. How social production transforms markets and freedom. New Haven: Yale University Press.

Benkler, Y. (2013). Commons and Growth: The Essential Role of Open Commons in Market Economies. University of Chicago Law Revue 80(3): 1499.

Berkes, F, Feeny, D, McCay, B. J and Acheson, J. M (1989). The Benefits of the Commons. Nature 340(6229): 91-93.

Bettinger, R.L. (2015). Orderly Anarchy: Socio-political Evolution in Aboriginal California. University of California Press. 
Blackmar, E. (2006). Appropriating the commons: The tragedy of property rights discourse. In S. Low and N. Smith, eds. The politics of public space. New York: Routledge. Pp. 49-80.

Bloemen, S. and D. Hammerstein (2015). The EU and the commons: A commons approach to European knowledge policy. Commons Network in cooperation with Heinrich Böll Stiftung Berlin/Brussels http://commonsnetwork.eu/wp-content/uploads/2015/06/A-Commons-Approachto-European-Knowledge-Policy.pdf

Bollier, D. (2010). Imagining a New Politics of the Commons. Posted on 9 October 2010. http://www.onthecommons.org/imagining-new-politics-commons

Bollier, D. (2011). The commons, short and sweet. http://bollier.org/commons-short-and-sweet

Bollier, D. and S. Helfrich (2015a). Overture. In: Bollier, D. and S. Helfrich (eds.) Patterns of commoning. Commons Strategy Group and Off the Common Press. Pp. 18-31

Bollier, D. and S. Helfrich, eds. (2015b) Patterns of commoning. Commons Strategy Group and Off the Common Press.

Boulanger, P.M. (2010). Three strategies for sustainable consumption. S.A.P.I.EN.S vol 3 (2). http://sapiens.revues.org/1022

Bové, J. and F. Dufour (2001). The world is not for sale. Farmers against junk food. London: Verso.

Bowles, S. \& H. Gintis (2013). A Cooperative Species: Human Reciprocity and Its Evolution. Princeton University Press.

Brown, K. M. (2006a). New Challenges for Old Commons: The Role of Historical Common Land in Contemporary Rural Spaces. Scottish Geographical Journal 122(2):109-129.

doi:10.1080/00369220600917412.

Brown, K. M. (2006b). Common Land in Western Europe: Anachronism or Opportunity for Sustainable Rural Development? IASCP Europe Regional Meeting: Building the European Commons: From Open Fields to Open Source. Brescia - Italy.

Brown, P.C. (2011). Cultivating commons: joint ownership of arable land in early modern Japan. Honolulu: University of Hawaii Press.

Brousseau, E., T. Dedeurwaerdere and B. Siebenhuner (2012). Reflexive governance for global public goods. The MIT press, Boston.

Buchanan, J. (1965) An economic theory of clubs. Economica, 32: 1-14.

Buchanan, J. and R. Musgrave (1999). Public Finance and Public Choice: Two Contrasting Visions of the State. MIT Press, Cambridge.

Buck, S.J. (1998). The Global Commons: An Introduction. Island Press.

Buckland, W.W. (1931). The main institutions of Roman private law. University Press, Cambridge. 
Bullock, A. and S. Trombley, eds. (1999). The New Fontana Dictionary of Modern Thought. Harper Collins, London.

Burnell, P.J. (2008) International democracy promotion: a role for public goods theory? Contemporary Politics 14(1): 37-52.

Caffentzis, G. (2012). A Tale of Two Conferences: Globalization, the Crisis of Neoliberalism and Question of the Commons. Borderlands 11(2). http://www.borderlands.net.au/vol11no2 2012/caffentzis globalization.pdf

Capra, F. and U. Mattei (2015). The ecology of law: toward a legal system in tune with Nature and community. Berrett-Koehler Publishers;

Carbone, M. (2007). Supporting or Resisting Global Public Goods? The Policy Dimension of a Contested Concept. Global Governance, 13(2): 179-198.

Carlson, J. and M.J. Chappell (2015). Deepening food democracy. Institute for Agriculture and Trade Policy, Minneapolis.

Charbonnier, P. and D. Festa (2016). Bien communs, beni comuni. Tracés. Revue de Sciences humaines [En ligne] 16 | 2016 http://traces.revues.org/6622

Chepstow-Lusty, A.J., M. R. Frogley, B. S. Bauer, M. J. Leng, K. P. Boessenkool, C. Carcaillet, A. A. Ali, and Gioda, A. (2009). Putting the rise of the Inca Empire within a climatic and land management context. Clim. Past, 5, 375-388. www.clim-past.net/5/375/2009/

Clausen, L.T. (2016). Reinventing the commons. How action research can support the renewal of sustainable communities. In: H.P. Hansen, B.S. Nielsen, N. Sriskandarajah and E. Gunnarsson, eds. Commons, Sustainability, Democratization: Action Research and the Basic renewal of society. Routledge, New York and London. Pp 29-52.

Coase, R.H. (1960). The Problem of Social Cost. Journal of Law and Economics 3: 1-44

Cogolati, S. (2016). Global Public Goods or Commons as a lens to development. Paper presented at Doctoral Seminar "The Law of the Commons", University of Zurich, 24 November 2016.

Cornes, R. and T. Sandler (1994). Are Public Goods Myths? Journal of Theoretical Politics 6(3): 369385

Dardot, P. and C. Laval (2014). Commun, essai sur la révolution au XXIº siècle. Paris, Le Découverte.

Dawkins, S. (1976). The selfish gene. Oxford University Press

De Angelis, M. (2007). The beginning of history: value struggles and global capital. London: Pluto Pr

De Angelis, M. and D. Harvei (2013). The commons. In: M. Parker, G. Cheney, V. Fournier and C. Land. The Routledge companion to alternative organisation. London:Routledge. Pp. 280-294.

De Moor, T. (2011). From Common Pastures to Global Commons: a Historical Perspective on Interdisciplinary Approaches to Commons. Natures Sciences Sociétés, 19 (4) : 422-431. 
De Moor, M. (2013). Homo cooperans. Institutions for collective action and the compassionate society. Inaugural Lecture, August. Utrecht University.

De Moor, T. (2015). The dilemma of the commoners: Understanding the use of common-pool resources in long-term perspective. Cambridge University Press.

De Moor, T. M. Laborda-Pemán, J.M. Lana-Berasain, R. van Weeren \& A. Winchester (2016). Ruling the Commons. Introducing a new methodology for the analysis of historical commons. International Journal of the Commons 10(2): 529-588. DOI: http://doi.org/10.18352/ijc.760

De Moor, M., L. Shaw-Taylor and P. Warde, eds. (2002). The Management of Common Land in North West Europe, c. 1500-1850. Turnhout: Brepols Publishers.

De Schutter, O. and J. Lenoble, eds. (2010). Reflexive Governance: Redefining the Public Interest in a Pluralist World. Hart Publishing, Oxford, UK and Portland, Oregon, USA.

De Waal, F. (2006). Primates and Philosophers: How Morality Evolved. Princeton University Press.

Dedeurwaerdere, T. (2014). Sustainability science for strong sustainability. Edward Elgar, Cheltenham, UK.

Demsetz, H. (1967). Toward a theory of property rights. American Economic Review, 57: 347-359

Deneulin, S. and Townsend, N. (2007). Public Goods, Global Public Goods and the Common Good. International Journal of Social Economics, 34 (1-2): 19-36.

Desai, M., 2003. Public Goods: A Historical Perspective. In: Kaul, I., Conceição, P., Le Goulven, K., Mendoza, R.U. (Eds.). Providing Global Public Goods: Managing Globalization. Oxford University Press, New York. http://www.ses.unam.mx/curso2014/pdf/Desai.pdf (Accessed on 5 November 2016)

Desmarais-Tremblay, M. (2014). On the Definition of Public Goods. Assessing Richard A. Musgrave's contribution; Documents de travail du Centre d'Economie de la Sorbonne 2014.04 https://halshs.archives-ouvertes.fr/halshs-00951577/document

Diamond, J. (1997). Guns, germs and steel. A short history of everybody for the last 13,000 years. London: Vintage.

Ege, R. and H. Igersheim (2010). Rawls's justice theory and its relations to the concept of merit goods. The European Journal of the History of Economic Thought 17(4): 1001-1030.

Engle-Merry, S. (1988). Legal Pluralism. Law \& Society Review 22 (5):869-896

EU (2014). European Commission Implementing Decision adopting a Multiannual Indicative Programme for the Thematic Programme 'Global Public Goods and Challenges' for the period 20142020. C(2014)5072. https://ec.europa.eu/europeaid/commision-implementing-decision-adoptingmultiannual-indicative-programme-thematic-programme-global en (Accessed 3 April 2017).

FAO (2002). The state of food and agriculture. FAO Rome.

Federici, S. (2014). Caliban and the witch. Women, the body and primitive accumulation. Autonomedia: Brooklyn, New York. 
Ferrando, T. (2016). Il sistema cibo come bene comune. In A. Quarta and M. Spanò, eds. Beni communi 2.0. Contro-egemonia e nuove istituzioni. Mimesis Edizioni, Milan. Pp. 99-109.

Fiske, A. P. (1991). Structures of Social Life: The Four Elementary Forms of Human Relations. New York: Free Press.

Folke, C. (2004). Traditional Knowledge in Social-Ecological Systems. Ecology and Society 9(3): 7.

Foucault, M. (1993). About the beginnings of the hermenuetics of the Self: Two Lectures at Dartmouth. Political Theory: 198-227.

Fraser, E.D.G. and A. Rimas (2011). Empires of food. Feast, famine and the rise and fall of civilizations. London: Arrow Books.

Friedmann, H. (2015). Governing land and landscapes: Political ecology of enclosures and commons. Canadian Food Studies 2(2): 23-31

Frischmann, B.M. (2013). Two enduring lessons from Elinor Ostrom. Journal of Institutional Economics 9 (4): $387-406$

Fuys, A., E. Mwangi and S. Dohrn (2008). Securing Common Property Regimes in a Globalizing World. Synthesis of 41 Case Studies on Common Property Regimes from Asia, Africa, Europe and Latin America. CAPRI programme and International Land Coalition, Rome.

http://www.landcoalition.org/sites/default/files/documents/resources/ilc_securing_common_prope rty_regimes_e.pdf

Galbraith, J.K. (1958). Affluent Society. Boston: Houghton Mifflin.

Gerber, J.-D., S. Nahrath, E. Reynard and L. Thomi (2008). The role of common pool resource institutions in the implementation of Swiss natural resource management policy. International Journal of the Commons 2(2): 222-247.

Gopal, L. (1961). Ownership of Agricultural Land in Ancient India. Journal of the Economic and Social History of the Orient 4-3: 240-263.

Grupo Montes Vecinales IDEGA (2013). La política forestal gallega en los montes vecinales en mano común. Ambienta 104: 114-125.

Gudynas, E. (2011). Buen Vivir: Today's tomorrow. Development 54(4): 441-447

Hampson, F.O. and J.B. Hay (2004). Review essay: Viva Vox Populi quick check. Global Governance 10(2): 247-264.

Hanachi, M., T. Dedeurwaerdere and J.L. Vivero-Pol (2016). Overcoming the tragedy of the commons in crop disease management. The role of locally evolved institutional arrangements in the YuanYang Terraces traditional agro-ecological system. Paper presented at the International Conference "Du vivant au social: les semences en question" (Lovain-la-Neuve, 6 October 2016).

Hardin, G. (1968). The Tragedy of the Commons. Science 168, December 13. 
Hardt, M. and A. Negri (2004). Multitude: War and Democracy in the Age of Empire. New York: Penguin Press.

Hardt, M. and A. Negri (2009). Commonwealth. Harvard University Press, Cambridge.

Harris, K.R. (2007). Was the Inca Empire a socialist state? A historical discussion. Historia 16: 54-60.

Harvey, M. A., A. McMeekin, S. Randles, D. Southerton, B. Tether and A. Warde (2001). Between demand and consumption: A framework for research. CRIC Discussion paper $\mathrm{N}^{\circ} 40$. University of Manchester.

Helfrich, S. (2016). State Power and Commoning. Paper prepared for the Conference of the Agence Francais de Developpement - Communs et Développement; Paris, December 1-2, 2016

http://communsetdeveloppement-afd2016.com/uploads/event member/116769/silkehelfrich.1.pdf

Helfrich, S., R. Kuhlen, W. Sachs and C. Siefkes (2010). The Commons - Prosperity by Sharing. Heinrich Böll Foundation. www.boell.de/economysocial/economy/economy-commons-report10489.html (Accessed on 3 April 2017).

Henrich, J., McElreath, R., Barr, A., Ensminger, J., Barrett, C., Bolyanatz, A., Henrich, N. (2006). Costly punishment across human societies. Science, 312(5781): 1767-1770

Hess, C. and E. Ostrom, eds. (2007). Understanding Knowledge as a Commons: From Theory to Practice. MIT Press, Cambridge, MA.

Hjorth Agerskov, A. (2005). Global public goods and development. A guide for policy makers. World Bank seminar series, 12 May, Kobe University.

Hobbes, T. (1651). Leviathan. Oxford University Press (re-edited in 1996).

Holcombe, R. (1997). A Theory of the Theory of Public Goods. Review of Austrian Economics 10 (1).

Holtermann, S. (1972). Externalities and Public Goods. Economica 39(153): 78-87.

Honoré, A.M. (1961). Ownership. Making law bind: essays legal and philosophical. In: Guest AG, ed. Oxford essays in jurisprudence: a collaborative work. Oxford: Oxford University Press. Pp. 107-147.

Hugon, P. (2004). Global public goods and the transnational level of regulation. Issues on Regulation Theory 4: 1-3. April. http://webcom.upmf-

grenoble.fr/regulation/Issue Regulation theory/LR48english.pdf

Ike, D.N. (1984). The system of land rights in Nigerian agriculture. The American Journal of Economics and Sociology 43 (4): 469-480

Illich, I. (1973). Tools of conviviality. Harper Row Publishers, New York.

Jeffrey, A., C. McFarlane and A. Vasudevan (2012). Rethinking Enclosure: Space, Subjectivity and the Commons. Antipode, 44(4): 1247-1267. DOI : 10.1111/j.1467-8330.2011.00954.x

Jerram, L. (2015). The false promise of the commons: historical fantasies, sexuality and the "reallyexisting" urban commons of modernity. In Burch, C. \& M. Kornberger, eds. Urban commons.

Rethinking the city. Routledge. Pp. 47-67. 
Johnston, J. (2008). Counterhegemony or Bourgeois Piggery? Food Politics and the Case of FoodShare. In: Wright, W., Middendorf, G., (Eds.). The Fight Over Food: Producers, Consumers, and Activists Challenge the Global Food System. Pennsylvania State University, pp 93-120.

Jones, A.H.M. (1986). The Later Roman Empire, 284-602: A Social, Economic, and Administrative Survey. Baltimore: The Johns Hopkins University Press.

Jones, G.A. and P.M. Ward (1998). Privatizing the commons: reforming the ejido and urban development in Mexico. International Journal of Urban and Regional Research 22 (1): 76-93.

Kallhoff, A. (2014). Why societies need public goods. Critical Review of International Social and Political Philosophy 17(6): 635-651.

Kaplan, D.M. (2012). Introduction. In D.M. Kaplan, ed. The Philosophy of Food. Berkeley: University of California Press. Pp 1-14.

Karatani, K. (2014). The Structure of World History: From Modes of Production to Modes of Exchange. Duke University Press, Durham, North Carolina.

Katz, F. (1972). The Ancient American Civilizations. Littlehampton Book Services Ltd

Kaul, I., O. Grunberg and M. A. Stern (1999). Global public goods: international cooperation in the 21st century. New York: Oxford University Press

Kaul, I., P. Conceição, K. Le Goulven and R.U. Mendoza, eds. (2003). Providing Global Public Goods: Managing Globalization. New York: Oxford University Press,. DOI: 10.1093/0195157400.001.0001

Kaul, I. and R.U. Mendoza (2003). Advancing the concept of public goods. In: I. Kaul, P. Conceição, K. Le Goulven, and R.U. Mendoza, eds. Providing Global public goods: managing globalization. New York: Oxford University Press.

Kent, G. (1978). Fisheries and the Law of the Sea: A Common Heritage Approach. Ocean Management 4: 1-20. http://www2.hawaii.edu/ kent/FisheriesandLOS.pdf

Kent, G. (2015). Food systems, agriculture, society. How to end hunger. World Nutrition 6(3): 170183.

Kindleberger, C.P. (1986). International Public Goods without International Government. The American Economic Review 76(1): 1-13

Kingi, T.T. and T.F. Kompas (2005). Communal Land Ownership and Agricultural Development: Overcoming Technical Efficiency Constraints Among Fiji's Indigenous Sugercane Growers. International and Development Economics Working Papers idec05-11, Australia National University. https://crawford.anu.edu.au/degrees/idec/working_papers/IDEC05-11.pdf

Knox, A., R. Giovarelli, M. Forman and M. Shelton (2012). Integrating customary land tenure into statutory land law. Washington: USAID, United States Agency for International Development. https://www.land-links.org/wp-

content/uploads/2016/09/USAID_Land_Tenure_PRRG_Integrating_Customary_Land_Tenure_Into_St atutory_Land_Law.pdf (accessed on 3 April 2017). 
Kostakis, V. and M. Bauwens (2014). Network society and future scenarios for a collaborative economy. London: Palgrave MacMillan.

Kropotkin, P. (1902). Mutual Aid: A Factor of Evolution. 2009. London: Freedom Press.

Kugelman, M. and S. L. Levenstein (2013). The Global Farms Race: Land Grabs, Agricultural Investment and the Scramble for Food Security. Island Press

La Mela, M. (2014). Property rights in conflict: wild berry picking and the Nordic tradition of allemansrätt. Scandinavian Economic History Review. doi:10.1080/03585522.2013.876928

Laborda-Pemán, M., (2015). Book review. Derek Wall. The Commons in History. Culture, Conflict, and Ecology. 2014. International Journal of the Commons 9(1): 466-468.

Laerhoven, F., and E. Berge (2011). The 20th Anniversary of Elinor Ostrom's Governing the Commons. International Journal of the Commons, 5(1), 1-8.

Lana-Berasain, J.M. (2008). From equilibrium to equity. The survival of the commons in the Ebro Basin, Navarra: from the $15^{\text {th }}$ to the $20^{\text {th }}$ centuries. International Journal of the Commons 2: $162-191$.

Lana-Berasain, JM. and I. Iriarte-Goni (2015). Commons and the legacy of the past. Regulation and uses of common lands in twentieth-century Spain. International Journal of the Commons 9 (2).

Le Roy, E. (2015). How I Have Been Conducting Research on the Commons for Thirty Years Without Knowing It. In: Bollier, D. and S. Helfrich (eds.) Patterns of commoning. Commons Strategy Group and Off the Common Press. Pp.

Leonard, T.C. (2009). Origins of the Myth of Social Darwinism: The Ambiguous Legacy of Richard Hofstadter's Social Darwinism in American Thought. Journal of Economic Behavior and Organization 71: $37-51$

Lessig, L. (2001). The future of ideas: The fate of the commons in a connected world. New York: Random House.

Light, A. (2000). Public goods, future generations, and environmental quality. In: A. Anton, M. Fisk \& N. Holmstom, eds. Public Goods: A New Direction in Political Morality. Westview Press, Boulder, CO

Linebaugh P. (2008). The Magna Carta manifesto. Liberties and commons for all. Oakland: University of California Press.

Locke, J. (1690). Second Treatise of Government. An essay concerning the true original, extent and end of civil government In: Cox, R. ed., 1982. Wheeling, IL: Harlan Davidson.

Lopes, L.F.G., Bento, J.M.R.S., Cristovão, A.F.A.C., Baptista, F.O., 2013. Institutionalization of common land in Portugal: Tragic trends between "Commons" and "Anticommons". Land Use Policy, 35: 85-94.

Lucchi, N. (2013). Understanding genetic information as a commons: from bioprospecting to personalized medicine. International Journal of the Commons 7 (2): 313-338.

Macé, A. (2014). Deux formes du commun en Grèce ancienne. Annales. Histoire, Sciences sociales 69(3) : 659-688. 
Macpherson, C.B. (1971). The Political Theory of Possessive Individualism (Hobbes to Locke). Oxford: Clarendon Press.

Madison, M. J., Frischmann, B. M. and K. J. Strandburg (2010). Constructing Commons in the Cultural Environment. Cornell Law Review, 95(4): 657-709.

Magdoff, F. and B. Tokar, eds. (2010). Agriculture and food in crisis. Conflict, resistance, and renewal. New York: Monthly Review Press.

Mattei, U. (2011). The State, the Market, and some Preliminary Question about the Commons (English Version). Available at: http://works.bepress.com/ugo_mattei/40

Mattei, U. (2012). First thoughts for a phenomenology of the commons. In: Bollier, D. and S. Helfrich, Eds. The wealth of the commons. A world beyond market and state. Amherst, MA: Levellers Press.

Mattei, U. (2013a). Bienes Comunes. Editorial Trotta. Madrid.

Mattei, U. (2013b). Protecting the Commons: water, culture, and nature. The Commons Movement in the Italian Struggle against Neoliberal Governance. South Atlantic Quarterly 112(2): 366-376.

Mauss, M. (1970). The Gift: Forms and Functions of Exchange in Archaic Societies. London: Cohen \& West.

McCarthy J. (2005). Commons as Counterhegemonic Projects. Capitalism, Nature, Socialism 16(1): 924.

McCloskey, D.N. (1991). The Prudent Peasant: New Findings on Open Fields. Journal of Economic History 51: 343-356.

McEwan. G.F. (2008). The Incas: New Perspectives. W. W. Norton \& Company

McMichael, P. (2000). The power of food. Agriculture and Human Values 17: 21-33.

Mears, T.L. (2008). Analysis of M. Ortolan's Institutes of Justinian including the history and generalization of Roman law. The Lawbook Exchange Ltd, New Jersey.

Meinzen-Dick, R., E. Mwangi and S. Dohrn (2006). Securing the commons. CGIAR Systemwide program on collective action and property rights. Policy Brief $n 4$.

Milun, K. (2011). The Political Uncommons. The Cross-Cultural Logic of the Global Commons. Ashgate, Surrey, UK.

Montanori, M. (2006). Food is culture. Arts and traditions on the table. New York: Columbia University Press.

Moore, D. (2004). The Second Age of the Third World: from primitive accumulation to global public goods? Third World Quarterly 25(1): 87-109.

Mortazavi, R. (1997). The right of public access in Sweden. Annals of Tourism Research 24(3): 609623 
Musgrave, R.A. (1939). The Voluntary Exchange Theory of Public Economy. The Quarterly Journal of Economics, 53(2): 213-237.

Musgrave, R.A. (1959). The Theory of Public Finance, pp. 13-15.

Musgrave, R.A. (1983). Samuelson on Public Goods. In Paul Samuelson and Modern Economic Theory. Reprinted in Public Finance in a Democratic Society. Wheatsheaf Books. 1986.

Musgrave, R.A. and P.B. Musgrave (1973). Public Finance in Theory and Practice. New York: McGraw Hill, first edition.

Neeson, J.M. (1993). Commoners: common right, enclosure and social change in England, 1700-1820. Cambridge University Press.

Netting, R.M. (1981). Balancing on an Alp: ecological change and continuity in a Swiss mountain village. Cambridge University Press, Cambridge.

Newitz, A. (2012). The greatest mystery of the Inca Empire was its strange economy. Posted on March 2012. Available at: http://io9.com/5872764/the-greatest-mystery-of-the-inca-empire-was-itsstrange-economy

Nozick, R. (1974). Anarchy, State, and Utopia. Basic Books.

Olson, M (1965). The Logic of Collective Action: Public Goods and the Theory of Groups.

O'Neill, J. (2001). Property, Care, and Environment. Environment and Planning C: Government and Policy 19: 695-711.

Ostrom, E. (1990) Governing the Commons: The Evolution of Institutions for Collective Action. Cambridge University Press, New York.

Ostrom, E. (2005). Understanding institutional diversity. Princeton University Press.

Ostrom, E. (2009). A polycentric approach to climate change. Policy Research working paper WPS 5095. World Bank, Washington, DC.

Ostrom, V. and Ostrom, E. (1977). Public goods and public choices. In E.S. Savas, ed. Alternatives for delivering public services: toward improved performance. Boulder, Colorado, USA, Westview Press.

Ostrom, E., R. Gardner and J. Walker (1994). Rules, Games, and Common-pool Resources. The University of Michigan Press, Ann Arbor.

Page, H. (2013). Global governance and food security as global public good. New York: Center on International Cooperation, New York University.

Paine, T. (1797). Agrarian Justice. In M. Philp, ed. (1995). Thomas Paine: Rights of Man, Commons Sense and Other Political Writings. Oxford: Oxford University Press.

Perilleux, A. and M. Nyssens (2016). Understanding Cooperative Finance as a New Common. Discussion Paper 2016-2. Institute de Recherches Economiques de Sociales. Universite catholique de Louvain. http://sites.uclouvain.be/econ/DP/IRES/201602.pdf 
Pettenati, G. and A. Toldo (2016). Il sistema alimentare locale è un bene comune? In: Ciaffi, D. F. De Filippi, G. Marra, E. Saporit, eds. (2016). Cibo, Cittadini e Spazi Urbani. Verso un'amministrazione condivisa dell' Urban Food Policy di Torino. Quaderno Labsus, Laboratorio per la Sussidiarietà, Roma. Pp 15-17. http://www.labsus.org/wp-content/uploads/2017/01/CIBO-CITTADINI-E-SPAZI-URBANI.pdf

Pickhardt, M. (2002), 'Fifty Years after Samuelson's "The Pure Theory of Public Expenditure": What Are We Left With?' paper given at 58th Congress of the International Institute of Public Finace (IIPF), Helsinki, 26-29 August.

Polanyi, K. (1944). The great transformation: the political and economic origins of our time. Reprinted in 2001. Beacon Press, Boston.

Quilligan, J. (2012). Why Distinguish Common Goods from Public Goods? In Bollier, D. \& S. Helfrich, eds. (2012). The Wealth of the Commons. A world beyond market \& state. Levellers Press. Amherst, MA. Abridged version available at http://p2pfoundation.net/Public Goods vs Common Goods

Rand, A. (1964). The virtue of selfishness. New York: Penguin.

Rawls, J. (1971). A Theory of Justice. Cambridge, Belknap Press.

Renger, J.M. (1995). Institutional, communal, and individual ownership or possession of arable land in Ancient Mesopotamia from the end of the fourth to the end of the first Millennium B.C. ChicagoKent Law Review 71(1): Article 11.

Robson, J. and G. Lichtenstein (2013). Special Issue on Latin American Commons: An Introduction. Journal of Latin American Geography 12(1): 1-4

Rocha, C. (2007). Food Insecurity as Market Failure: A Contribution from Economics. Journal of Hunger and Environmental Nutrition. 1(4): 5-22.

Rodotà S. (2013). Constituting the Commons in the Context of State, Law and Politics. In: Economics and the Common(s): From Seed Form to Core Paradigm. A report on an international conference on the future of the commons, Berlin, Heinrich Böll Foundation, pp. 6-8.

Rose, C.M. (1986). The Comedy of the Commons: Commerce, Custom, and Inherently Public Property. The University of Chicago Law Review 53(3): 711-781.

Ruivenkamp, G. and A. Hilton (forthcoming). Introduction. In: Ruivenkamp, G. and A. Hilton, eds. Perspectives on commoning. Autonomist principles and practices. Zed Books, London.

Samuelson, P. A. (1954). The Pure Theory of Public Expenditure. Review of Economics and Statistics 56: $387-89$

Samuelson, P. (1955). A diagramatic exposition of a theory of public expenditure. Review of Economics and Statistics 37: 350-56.

Sandel, M.J. (2009). Justice: What's the right thing to do? Farrar, Straus and Giroux: New York.

Sandel, M.J. (2013). What money can't buy: the moral limits of markets. New York: Farrar, Straus and Giroux. 
Sands, P. (2003). Principles of International Environment Law, Cambridge University Press, Second Edition

Schelling, T.C. (1984). Self-Command in Practice, in Policy, and in a Theory of Rational Choice. The American Economic Review, 74(2): 1-11

Scherb, A., A. Palmer, S. Frattaroli and K. Pollack (2012). Exploring Food System Policy: A Survey of Food Policy Councils in the United States. Journal of Agriculture, Food Systems and Community Development 2(4). DOI: http://dx.doi.org/10.5304/jafscd.2012.024.007

Schlager, E. and E. Ostrom (1992). Property-rights regimes and natural resources: a conceptual analysis. Nature 413:591-596.

Schuftan C. (2015). Climate, Development. Food prices and food wars. World Nutrition 6(3): $210-211$

Sekera, J. (2014). Re-thinking the Definition of "Public Goods". Realworld Economics Review Blog, 9 July 2014. Accesed on 29 September 2015 at https://rwer.wordpress.com/2014/07/09/re-thinkingthe-definition-of-public-goods/

Serra, R., P. Ferreira, I. Skulska, M. Alavez-Vargas, A. Salgado, J. Arriscado-Nunes and R. GarciaBarrios (2016). Education for Sustainability in the Context of Community Forestry. In P. Castro et al., (eds.). Biodiversity and Education for Sustainable Development. Springer International Publishing World Sustainability Series, Switzerland. Pp. 169-183.

Severino, J.M. (2001). Refonder I'aide au développement au XXle siècle. Critique internationale, 10: 75.

Shiva, V. (2005). Globalization's New Wars: Seed, Water and Life Forms. Women Unlimited, New Delhi.

Sider, G.M. (1980). The Ties That Bind: Culture and Agriculture, Property and Propriety in the Newfoundland Village Fishery. Social History. 5 (1): 2-3, 17. doi:10.1080/03071028008567469.

Siefkes, C. (2007). From Exchange to Contributions. Edition C. Siefkes, Berlin.

Simpson, J. and E. Weiner, eds. (1989). Oxford English Dictionary. 2nd ed. Oxford: Oxford Univ. Press.

Smith, A. (1776). An Inquiry into the Nature and Causes of the Wealth of Nations. London: W. Strahan.

Smith, H.E. (2000). Semicommon property rights and scattering in the open fields. The Journal of Legal Studies, 29-1: 131-169.

Soto-Fernandez, D. (2014). Re-inventing the commons. Rules, identity and environment in the (un)sustainability of Galician commons (NW Spain) since Franco's regime. Conference Paper at Workshop on Common People, Common Rules, Pamplona, October 2014. DOI:

10.13140/2.1.4707.1521

Sraffa, P. (1960). Production of commodities by means of commodities: prelude to a critique of economic theory. Cambridge: Cambridge University Press. 
Stiglitz, J.E. (1999). Knowledge as a Global Public Good. In I. Kaul, I. Grunberg and M. Stern (eds.). Global Public Goods: International Cooperation in the 21st Century. Oxford University Press, Oxford.

Strahilevitz, L. J. (2005). The right to destroy. The Yale Law Journal, 114, 781-854.

Strauss, L. (1952). On Locke's doctrine of natural right. The Philosophical Review, 61(4), 475-502.

Stretton, H. and L. Orchard (1994). Public Goods; Public Enterprise, Public Choice: Theoretical Foundations of the Contemporary Attack on Government.

Sturn, R. (2010). Public goods before Samuelson: interwar Finanzwissenschaft and Musgrave's synthesis The European Journal of the History of Economic Thought 17(2): 279-312.

Sunderlin, W.D., J. Hatcher and M. Liddle (2008). From Exclusion to Ownership? Challenges and Opportunities in Advancing Forest Tenure Reform. Published by Rights and Resources Initiative. The book is available at: http://www.rightsandresources.org/documents/files/doc_736.pdf

Sutcliffe, L., I. Paulini, G. Jones, R. Marggraf and N. Page (2013). Pastoral commons use in Romania and the role of the Common Agricultural Policy. International Journal of the Commons 7(1): 58-72

Szymanski, I.F. (2016). What is food? Networks and not commodities. In: M. Rawlinson, M.C., Ward, C. eds. The Routledge Handbook of Food Ethics. Routledge, Abingdon and New York, pp. 7-15

Tennis. J. T. (2008). Epistemology, Theory, and Methodology in Knowledge Organization: Toward a Classification, Metatheory, and Research Framework. Knowledge Organization 35(2/3): 102-112.

Thompson, E.P. (1993). Customs in Common: Studies in Traditional Popular Culture. New Press.

Timmermann, C. (2014). Limiting and facilitating access to innovations in medicine and agriculture: a brief exposition of the ethical arguments. Life Sciences, Society and Policy 2014, 10:8 doi:10.1186/s40504-014-0008-5

Toret, J. (Coord.) (2013). Tecnopolítica: la potencia de las multitudes conectadas. El sistema red 15M, un nuevo paradigma de la política distribuida. Barcelona: UOC-IN3. Retrieved from

http://journals.uoc.edu/index.php/in3-working-paper-series/article/view/1878/n13_toret

International Task Force on Global Public Goods (2006). Meeting Global Challenges: International Cooperation in the National Interest. Final Report. Stockholm, Sweden.

http://ycsg.yale.edu/sites/default/files/files/meeting global challenges global public goods.pdf (Accessed on 4 April 2017).

van Laerhoven, F. and E. Ostrom (2007). Traditions and Trends in the Study of the Commons. International Journal of the Commons 1(1): 3-28.

Van Tichelen, C. (2015). Les communs comme vecteur de transition écologique et sociale. Analyse à partir des potagers collectifs à Bruxelles. Unpublished thesis to get a MSc degree. Universite catholique de Louvain and Universite de Namur. https://issuu.com/fgfffg/docs/mtacoopeco2016vantichelen_tfe

Varian, H.R. (1993). Markets for public goods? Critical Review: A Journal of Politics and Society 7(4). 
Vasile, M. and L. Mantescu (2009). Property reforms in rural Romania and community-based forests. Sociologie Romaneasca [Romanian Sociology] 7(2): 95-113

Verhaegen, E. (2015). La forge conceptuelle. Le "commun" comme réinterprétation de la propriété. Recherches sociologiques et anthropologiques 46-2 : 111-131. http://rsa.revues.org/1547

Vira, B., C. Wildburger and S. Mansourian, eds. (2015). Forests, Trees and Landscapes for Food Security and Nutrition. A Global Assessment Report. IUFRO World Series Volume 33. Vienna.

Vivero-Pol, J.L. (2013). Food as a commons: reframing the narrative of the food system. SSRN working paper. April 2013. http://papers.ssrn.com/sol3/papers.cfm?abstract id=2255447

Vivero-Pol J.L. (2015). Food is a public good. World Nutrition 6, 4: 306-309

Vivero-Pol, J.L. (2017). Food as Commons or Commodity? Exploring the Links between Normative Valuations and Agency in Food Transition. Sustainability 9(3), 442; doi:10.3390/su9030442

Vivero-Pol, J.L. (forthcoming, 2017a). The idea of food as commons or commodity in the academia. A systematic review of English scholarly texts. Journal of Rural Studies

Vivero-Pol, J.L. (forthcoming, 2017b). Transition towards a food commons regime: re-commoning food to crowd-feed the world. In: Ruivenkamp, G. \& A. Hilton (eds.). Perspectives on Commoning: Autonomist Principles and Practices. Zed Books. Pp. 185-221.

Vivero-Pol, J.L. \& C. Schuftan (2016). No right to food and nutrition in the SDGs: mistake or success? BMJ Global Health 1: e000040. DOI: 10.1136/bmjgh-2016-000040

Vivier, N. (2002). The management and use of the commons in France in the eighteenth and nineteenth centuries. In: M. De Moor, L. Shaw-Taylor \& P. Warde, eds. The management of common land in north west Europe c. 1500-1850, pp. 143-171. Turnhout: Brepols Publishers.

Wall, D. (2014). The Commons in History. Culture, Conflict, and Ecology. MIT Press, Cambridge, USA.

Wallerstein, I., 2016. The scholarly mainstream and reality: are we at a turning point? In: I. Wallerstein, ed. Modern World-System in the Longue Duree. Routledge. Pp. 219-228.

Walljasper, J. (2010). All That We Share: How to Save the Economy, the Environment, the Internet, Democracy, Our Communities and Everything Else that Belongs to All of Us. The New Press.

Weston, B.H. and D. Bollier (2013). Green Governance: Ecological Survival, Human Rights, and the Law of the Commons. New York: Cambridge University Press.

White, A. and A. Martin (2008). Who owns the world's forests? Forest tenure and public forests in transition. Forest Trends \& Centre for International Environmental Law, Washington DC. http://www.cifor.org/publications/pdf_files/reports/tenurereport_whoowns.pdf

Widerquist, K. (2010). Lockean theories of property: justifications for unilateral appropiation. Public Reason 2 (1): 3-26.

Wilson, J., L. Yan and C. Wilson (2007). The precursors of governance in the Maine lobster fishery. PNAS 104 (39): 15212-15217. 
Wolf, M. (2012). The world's hunger for public goods. Financial Times, January 24, 2012. http://www.ft.com/cms/s/0/517e31c8-45bd-11e1-93f1-00144feabdc0.html\#axzz3n8xYg9Kt

Workshop on Governing Knowledge Commons (2014). An introduction to Knowledge Commons. 14 August 2014. http://knowledgecommons.net/downloads/Knowledge\%20Commons\%20Description.pdf (Accesed on 3 April 2017)

Wuyts, M. (1992). Deprivation and Public Need. In: Wuyts, M., Mackintosh, M. \& Hewitt, T. (1992). Development Policy and Public Action. Oxford: Oxford University Press/Open University.

Young, O.R., 2003. Taking stock: management pitfalls in fisheries science. Environment 45 (3): 24.

(c) 2017 by the authors. Licensee Preprints, Basel, Switzerland. This article is an open access article distributed under the terms and conditions of the Creative Commons by Attribution (CC-BY) license (http://creativecommons.org/licenses/by/4.0/). 